\title{
Seeing environmental injustices: the mechanics, devices and assumptions of environmental sustainability indices and indicators
}

\author{
Marina Requena-i-Mora ${ }^{1}$ \\ Dan Brockington \\ Jaume I University, Spain \\ University of Sheffield, UK \\ Refereed preprint Dec. 2021 awaits page numbers
}

\begin{abstract}
At the heart of any colonization project, and therefore any move to de-colonize, are ways of seeing nature and society, that then allow particular ways of governing each. This is plainly visible in a number of tools that exist to measure progress towards (or regress from) environmental sustainability. The tools use indices and indicators constructed mostly by environmental scientists and ecologists. As such, they are not neutral scientific instruments: they reflect the worldviews of their creators. These worldviews depend on three dimensions: the values they prioritize, the explanatory theories they use and the futures they envision. Through these means different tools produce conflicting notions of the sustainability of our economies and societies. In this article, we shed light onto the theoretical and epistemological assumptions that lie behind key international sustainability indices and indicators: the Environmental Performance Index, Domestic Material Consumption, Material Intensity, the Material Footprint, the Carbon Footprint, the Ecological Footprint and $\mathrm{CO}_{2}$ emissions (territorial). The variables included in these indices, the way they are measured, aggregated and weighted all imply a particular way of understanding the relationships between economy, society and environment. This divergence is most clearly visible in the fact that some indices are negatively correlated with each other. Where one index might plot growing environmental sustainability, another shows its decline. Our results highlight that those devices and the theories informing them are particularly interesting for way how colonialism is materialized. Some of these measurements hide the material roots of prosperity and the ecological (and economic) distributional conflicts exported to the poorer countries by the global North, and others show how its production and consumption levels are reliant upon a socio-ecological 'subsidy' imposed on Southern countries. These subsidies represent injustices that present a prima facie case for decolonizing indices and indicators of environmental governance.
\end{abstract}

Keywords: colonization, ecological distributional conflicts, green growth, degrowth, political ecology

\section{Résumé}

Au cœur de tout projet de colonisation, et donc de tout mouvement de décolonisation, se trouvent des manières particulières de voir la nature et la société, qui permettent ensuite des manières particulières de gouverner chacune. Il existe un certain nombre d'outils pour mesurer les progrès vers (ou loin de) la durabilité environnementale. De tels outils utilisent des indices et des indicateurs, mais ce ne sont pas des instruments scientifiques neutres. Ils reflètent la vision du monde de leurs créateurs. Ces visions du monde dépendent de

\footnotetext{
${ }^{1}$ Dr. Marina Requena-i-Mora, Assistant Professor, Jaume I University, Spain and researcher at the University of Sheffield, UK. Email: mrequena "at" uji.es. Professor Dan Brockington, Director, Sheffield Institute for International Development, University of Sheffield, UK. Email: d.brockington "at" sheffield.ac.uk. Acknowledgements: assistance provided by Pau Belda was greatly appreciated. Thanks to Rose Pritchard, Ernest Garcia, Joan Martinez-Alier and Andrea Jiménez for an interesting exchange that led to this article. Finally, we would like to offer our special thanks to anonymous reviewers and to the editors. This is the xx article in Dan Brockington, Esteve Corbera and Sara Maestre (eds.). 2021. "The challenges of decolonizing conservation", Special Section of the Journal of Political Ecology 28.
} 
trois dimensions: les valeurs qu'elles privilégient, les théories explicatives qu'elles utilisent et les futurs qu'elles envisagent. Par ces moyens, différents outils produisent des notions contradictoires de la durabilité de nos économies et sociétés. Cet article éclaire les hypothèses théoriques et épistémologiques qui sous-tendent les principaux indices et indicateurs internationaux de durabilité: 'The Environmental Performance Index, Domestic Material Consumption, Material Intensity, Material Footprint, Carbon Footprint, Ecological Footprint et les émissions de $\mathrm{CO}_{2}$ (territoriales).' Les variables incluses dans ces indices, la manière dont elles sont mesurées, agrégées et pondérées impliquent une manière particulière de comprendre les relations entre l'économie, la société et l'environnement. Cette divergence est plus clairement visible dans le fait que certains indices sont négativement corrélés entre eux. Là où un indice pourrait tracer une durabilité environnementale croissante, un autre montre son déclin. Nos résultats mettent en évidence que ces dispositifs et les théories qui les informent sont particulièrement intéressants pour la manière dont le colonialisme se matérialise. Certaines de ces mesures cachent les racines matérielles de la prospérité occidentale et des conflits de répartition écologiques (et économiques) exportés vers les pays les plus pauvres. Au contraire, d'autres mesures de durabilité environnementale montrent que les niveaux de production et de consommation au Nord dépendent d'une « subvention » socio-écologique imposée aux pays du Sud. Cette subvention représente des injustices qui constituent un argument de choix pour décoloniser les indices et indicateurs de gouvernance environnementale.Mots-clés: colonisation, conflits de répartition écologiques, croissance verte, décroissance, écologie politique

\section{Resum}

Al cor de qualsevol projecte de colonització, i per tant de qualsevol moviment de descolonització, hi ha formes particulars de veure la natura i la societat, que alhora permeten formes particulars de governar cadascuna d'aquestes esferes. Això és clarament visible en una sèrie d'eines que existeixen per mesurar el progrés (o la regressió) cap a la sostenibilitat. Aquestes eines utilitzen índexs i indicadors construïts a partir de determinades formes de mesurar el medi ambient i l'ecologia. Però no són instruments científics neutrals. Reflecteixen les cosmovisions dels seus creadors. Aquestes cosmovisions depenen de tres dimensions: els valors que es prioritzen, les teories explicatives que s'utilitzen i el futur que s'imagina. A través d'aquests mitjans, diferents eines produeixen nocions contradictòries sobre la sostenibilitat de les nostres economies i societats. Aquest treball treu a la llum els supòsits teòrics i epistemològics que que subjeuen dels principals índexs i indicadors de sostenibilitat internacional: l'Índex d'Acompliment Ambiental, el Consum Intern de Materials, la Intensitat Material, la Petjada Material, la Petjada de Carboni, la Petjada Ecològica i les Emissions de $\mathrm{CO}_{2}$ (territorials). Les variables incloses en aquests índexs, com es mesuren, agreguen i ponderen, impliquen una forma particular d'entendre les relacions entre economia, societat i medi ambient. Aquesta divergència s'aprecia empíricament en les correlacions inverses entre alguns dels indicadors i índexs. On un índex o indicador pot representar progrés, un altre mostra regressió. Els nostres resultats destaquen que aquests dispositius i les teories que els informen són particularment interessants per la forma en què es materialitza el colonialisme. Algunes d'aquestes mesures oculten les arrels materials de la prosperitat occidental i els conflictes distributius ecològics (i econòmics) exportats als països més pobres. Per contra, altres mesures de sostenibilitat ambiental mostren que els nivells de producció i consum de nord depenen d'un "subsidi" socioecològic imposat als països de sud. Aquest subsidi representa injustícies que presenten un cas primordial per descolonitzar índexs i indicadors de governança ambiental. Paraules clau: colonització, conflictes ecològics-distributius, creixement verd, decreixement, eoclogia política

\section{Resumen}

En el corazón de cualquier proyecto de colonización, y por lo tanto de cualquier movimiento de descolonización, hay formas particulares de ver la naturaleza y la sociedad, que a su vez permiten formas particulares de gobernar cada una de estas esferas. Esto es claramente visible en una serie de herramientas que existen para medir el progreso (o la regresión) hacia la sostenibilidad. Estas herramientas utilizan índices e indicadores construidos a partir de determinadas formas de medir el medio ambiente y la ecología. Pero no son instrumentos científicos neutrales. Reflejan las cosmovisiones de sus creadores. Estas cosmovisiones dependen de tres dimensiones: los valores que se priorizan, las teorías explicativas que se utilizan y el futuro que se imagina. A través de estos medios, diferentes herramientas producen nociones contradictorias sobre la sostenibilidad de nuestras economías y sociedades. Este trabajo saca a la luz los supuestos teóricos y epistemológicos que están detrás de los principales índices e indicadores de sostenibilidad internacional: el Índice de Desempeño Ambiental, el Consumo Interno de Materiales, la Intensidad del Material, la Huella 
Material, la Huella de Carbono, la Huella Ecológica y las emisiones de CO2 (territoriales). Las variables incluidas en estos índices, cómo se miden, agregan y ponderan, implican una forma particular de entender las relaciones entre economía, sociedad y medio ambiente. Dicha divergencia se aprecia empíricamente en las correlaciones inversas entre algunos de los indicadores e índices. Donde un índice o indicador puede representar progreso, otro muestra regresión. Nuestros resultados destacan que estos dispositivos y las teorías que los informan son particularmente interesantes para la forma en que se materializa el colonialismo. Algunas de estas medidas ocultan las raíces materiales de la prosperidad occidental y los conflictos distributivos ecológicos (y económicos) exportados a los países más pobres. Por el contrario, otras medidas de sostenibilidad ambiental muestran que los niveles de producción y consumo de norte dependen de un "subsidio" socioecológico impuesto a los países de sur. Este subsidio representa injusticias que presentan un caso primordial para descolonizar índices e indicadores de gobernanza ambiental.

Palabras clave: colonización, conflictos ecologico-distributivos, crecimiento verde, decrecimiento, ecología política

\section{Introduction}

A considerable number of indicators can be used to track different aspects of environmental change, degradation, and their amelioration across countries and over time. With so many indicators to consider, there is an understandable desire to reduce the number of variables monitored. One aggregate score is easier to compare than many separate numbers, so there have been diverse efforts to turn the multi-dimensional nature of environmental change into single composite indices. These are used in many situations to capture and simplify complex change.

According to Ravallion (2010), two broad types of composite indices of can be identified. In the first, the choices of the component series and the aggregation function are informed and constrained by a body of theory and practice from the literature. This is not the case for the second type, where the analyst identifies a set of indicators that are assumed to reflect various dimensions of a particular concept. An aggregate index is then constructed at the country level, usually after re-scaling or ranking the component series. Therefore, neither the component series "nor the aggregation function is pre-determined from theory and practice but are 'moving parts' of the index - key decision variables that the analyst is free to choose, largely unconstrained by economic or other theories intended to inform measurement practice" (Ravallion 2010: 3).

Ravallion is dismissive of the second type, calling them 'mash-up' indices. However, while their composition and construction may be arbitrary, there are more theoretical assumptions that lie behind them than Ravallion recognizes. Indeed, it is precisely in the composition and construction of mash-up indices that we can read the unstated, unwritten theories and politics that inform them. These indices are not just a means of aggregating facts about the world; they are also lenses into the minds of the aggregators, and the world they want to create. The plethora of indices and indicators of environmental performance and change are particularly interesting for the way in which they encourage us to view the world, and the unwritten theories and politics that inform these views. In other words, they embed in indices different ways in which environmental problems are framed (Lele et al. 2018). These framings depend in turn on three dimensions: the values they prioritize, the explanatory theories they use, and the futures they envision (ibid.). To understand and critically engage with environmental measurements it is necessary to remember the motivations and epistemologies that shape their construction (Thatcher et al. 2016).

Environmental studies are laden with values (Lele and Norgaard 1996). Environmental changes become "problems" only because some group of people in society consider them so. Environmental change is not just a process affecting physical phenomena: it is also human interests, priorities, hopes and desires that attribute negative or positive value to such changes (Lele et al. 2018). In the same way, any aims that are set, such as green growth or sustainable development, as well as the criteria and indicators that will be used to measure progress toward them, are value-laden. Values determine which environmental processes are seen as problems, in what sense and context, and shape the solutions that should be implemented in the future. In these values are found the theoretical influence that Ravallion missed. 
Mazzucato (2018) has pointed out that ascribing value, or the lack of it, has always involved socioeconomic arguments which derive from a particular political perspective. Sometimes this perspective is explicit and sometimes not. Therefore, the definition of value, and determination of what is valued, are always rooted in particular views of how society ought to be constructed. A classic example is how domestic labor (typically female) within families is (not) valued and (un)recognized by economists. The old (unfunny) joke that when an economist marries his housekeeper GDP declines, is premised on the fact that his wife's labor is not counted or valued by that economist professionally, however much he may profess to value it personally. Measurement, therefore, is never neutral. It is dependent on prior decisions of what needs to be measured. Therefore, in order to arrive at the understanding of value, "we need to go beyond seemingly scientific categorizations of activity and look at the socio-economic and political conflicts that underline them" (Mazzucato 2018: 15). This article responds to that challenge with respect to environmental sustainability indicators.

We will argue that we can see in these indices a key aspect of colonization (and therefore, also decolonization). At the heart of any colonization project is a particular way of seeing societies, places, and environments. These ways of seeing both create the need for colonization, and the mode of rule that then ensues. Colonialism should be understood in terms of its effects on power relations across borders and its reproduction by technocrats, universities, and governments within borders of colonized countries (Ricaurte, 2019). These forms of oppression should be seen through the lens of their effects on territories of marginalized and multiethnic populations. We must identify how colonization deployed as an internal, international, and transnational process that perpetuates social injustices, exploitation, and the diminishment of life on Earth (ibid.). The plethora of indices and indicators of environmental performance are particularly interesting for how colonialism is materialized. The indices can conceal, or portray, the ways in which some countries (in the global North) are consuming more natural resources, where these natural resources come from, and which countries (in the global South) are suffering ecological (and economic) distributional conflicts.

The article is structured as follows. First, we explain the nature and the origin of the seven indicators and indices. Second, we compare the different measures of environmental sustainability with each other and with measures of economic growth, demonstrating the contradictions between them. Then we try to explain what drives these contradictory results. In doing so we bring to light the ideological and theoretical assumptions and tricks that are behind these indices and indicators. This allows us to consider the role of indicators in colonizing, and therefore decolonizing environmental governance.

\section{The nature and origin of the different measures of environmental sustainability}

We have selected seven of the most widely used global sustainability indicators and indices. A brief introduction to them can be found in Table 1. We summarize the essentials below.

Domestic Material Consumption and Material Footprint are the total weight of raw material (biomass, minerals, metals and fossil fuels) used in a specific economy. Domestic Material Consumption does not include the material impact involved in the production and transport of imported goods (Wiedmann et al. 2015). Nor does Domestic Material Consumption take into account the materials needed along the supply chains of traded goods. Material Footprint, in contrast, accounts for the amount of all materials required along the supply chains of all goods and services finally consumed in a country. Therefore, Material Footprint is better at capturing the broader role in the global economy played by any one country since it is more comprehensive than Domestic Material Consumption. Both these indices are presented in per capita terms. A high score for both indicators implies poor environmental performance.

Material Intensity is the ratio of Domestic Material Consumption (in kilograms) to Gross Domestic Product (GDP) at constant prices (e.g. 2010 US\$). This indicator is normally used to express the level of efficiency in the use of raw materials. High Material Intensity scores indicate poor environmental performance, because this means that a lot of material has to be used to produce any given unit of GDP, whereas low scores indicate more efficient use. 


\begin{tabular}{|c|c|c|c|c|c|}
\hline $\begin{array}{l}\text { Indices and } \\
\text { Indicators }\end{array}$ & Acronym & What is measured & $\begin{array}{c}\text { Which international } \\
\text { organizations are } \\
\text { using it? }\end{array}$ & $\begin{array}{c}\text { Latest } \\
\text { data } \\
\text { available }\end{array}$ & Source \\
\hline $\begin{array}{l}\text { Environmental } \\
\text { Performance } \\
\text { Index }\end{array}$ & EPI & $\begin{array}{l}24 \text { indicators grouped within } 10 \text { issue categories: } \\
\text { Air Quality, Water \& Sanitation, Heavy Metals, } \\
\text { Biodiversity \& Habitat, Forests, Fisheries, Climate } \\
\text { \& Energy, Air Pollution, Water Resources, and } \\
\text { Agriculture and Covering two objectives: } \\
\text { Environmental health and Ecosystem vitality }\end{array}$ & $\begin{array}{l}\text { World Economic } \\
\text { Forum }\end{array}$ & 2018 & $\begin{array}{l}\text { Environmental } \\
\text { Performance } \\
\text { Index Database }\end{array}$ \\
\hline $\begin{array}{c}\text { Domestic } \\
\text { Material } \\
\text { Consumption } \\
\text { per capita }\end{array}$ & DMC & $\begin{array}{l}\text { Tons of material per capita (biomass, fossil fuel, } \\
\text { Metal Ores and Non-metallic minerals) directly } \\
\text { used by any economy (it does not include the } \\
\text { upstream raw materials related to imports and } \\
\text { exports originating from outside the national } \\
\text { economy) divided by population }\end{array}$ & \begin{tabular}{|l|} 
EUROSTAT (EU), \\
SDGs Goals 8 and 12 \\
(United Nations), \\
OECDE (Green \\
Growth Indicators)
\end{tabular} & 2017 & $\begin{array}{l}\text { UN } \\
\text { Environment } \\
\text { Programme } \\
\text { International } \\
\text { Resource Panel }\end{array}$ \\
\hline $\begin{array}{c}\text { Material } \\
\text { intensity } \\
\text { DMC/GDP }\end{array}$ & MI & $\begin{array}{l}\text { Kilograms of material (biomass, fossil fuel, metal } \\
\text { ores and non-metallic minerals) directly used by } \\
\text { any economy (it does not include the upstream raw } \\
\text { materials related to imports and exports originating } \\
\text { from outside the national economy) divided by } \\
\text { GDP (constant 2010 US\$) }\end{array}$ & \begin{tabular}{|} 
EUROSTAT (EU), \\
SDGs Goals 8 and 12 \\
(United Nations), \\
OCDE (2018)
\end{tabular} & 2017 & $\begin{array}{l}\text { UN } \\
\text { Environment } \\
\text { Programme } \\
\text { International } \\
\text { Resource Panel }\end{array}$ \\
\hline $\begin{array}{c}\text { Material } \\
\text { Footprint per } \\
\text { capita }\end{array}$ & MF & $\begin{array}{c}\text { Tons of materials per capita (biomass, fossil fuel, } \\
\text { metal ores and non-metallic minerals) associated } \\
\text { with the final demand for goods and services } \\
\text { divided by population }\end{array}$ & \begin{tabular}{|l|} 
EUROSTAT (EU), \\
SDGs Goals 8 and 12 \\
(United Nations), \\
OECD (green growth \\
indicators)
\end{tabular} & 2017 & \begin{tabular}{|c} 
UN \\
Environment \\
Programme \\
International \\
Resource Panel
\end{tabular} \\
\hline \begin{tabular}{c|} 
Ecological \\
Footprint per \\
capita
\end{tabular} & $\mathrm{EF}$ & $\begin{array}{c}\text { Global Hectares per capita of cropland, forestland, } \\
\text { fishing grounds, grazing land, built-up land and } \\
\text { carbon footprint }\end{array}$ & WWF & 2017 & $\begin{array}{l}\text { Global } \\
\text { Network } \\
\text { Footprint } \\
\text { database }\end{array}$ \\
\hline $\begin{array}{l}\text { Carbon } \\
\text { Footprint per } \\
\text { capita }\end{array}$ & CF & $\begin{array}{l}\text { Consumption-based } \mathrm{CO}_{2} \text { emissions (in } \mathrm{Mt} \mathrm{CO}_{2} \text {-eq } \\
\text { per capita). Accounts for emissions associated } \\
\text { with imported and exported goods. Consumption- } \\
\text { based reports the total emissions associated with } \\
\text { final demand in each country. }\end{array}$ & $\begin{array}{c}\text { EUROSTAT (EU), } \\
\text { OCDE (green growth } \\
\text { indicators) }\end{array}$ & 2017 & $\begin{array}{c}\text { Eora MRIO } \\
\text { database }\end{array}$ \\
\hline $\begin{array}{c}\mathrm{CO}_{2} \text { emissions } \\
\text { per capita } \\
\text { (Territorial) }\end{array}$ & $\mathrm{CO}_{2}$ & $\begin{array}{l}\text { Production-based } \mathrm{CO}_{2} \text { emissions (in } \mathrm{Mt} \mathrm{CO}_{2} \text {-eq } \\
\text { per capita). Emissions physically occurring in a } \\
\text { country are its territorial emissions }\end{array}$ & \begin{tabular}{|c|} 
EUROSTAT, SDGs \\
Goal 9, OCDE, World \\
Bank, CDIAC, \\
International Energy \\
Agency, the JRC, \\
UNFCCC, IPCC
\end{tabular} & 2017 & $\begin{array}{c}\text { Eora MRIO } \\
\text { database }\end{array}$ \\
\hline
\end{tabular}

Table 1: Selected Environmental Sustainability indices and indicators. Source: own table.

The Ecological Footprint is measured using a standardized area unit equivalent to a 'global hectare' (gha) ${ }^{2}$ and global hectares per capita (gha/cap). The Ecological Footprint of each country is the sum of six

${ }^{2}$ Global hectares are the accounting unit for the Ecological Footprint and Biocapacity. The Ecological Footprint measures the amount of material consumed by a person (tonnes per year) divided by the yield of the specific land or sea area (annual 
components (cropland, forestland, fishing grounds, grazing land, the built-up area, and carbon footprint). The higher the Ecological Footprint, the worst its environmental performance. Consumption-based accounting of carbon emissions (also called the Carbon Footprint) measures emissions associated with imported and exported goods and materials.

The Carbon Footprint reports the total emissions associated with each country and can be calculated using a global multi-region input-output (MRIO) model which traces global supply chains. A Carbon Footprint is measured using carbon dioxide equivalent $\left(\mathrm{CO}_{2}-\mathrm{eq}\right) \cdot{ }^{3}$ Emissions physically occurring in a country are its territorial emissions (henceforth, $\mathrm{CO}_{2}$ emissions). This is sometimes called production-based accounting. This is the standard reporting of GHG emissions as reported by CDIAC, IEA, the JRC EDGAR database, UNFCCC, and others. Carbon Footprint and $\mathrm{CO}_{2}$ emissions are presented in per capita terms. A high score for both indicators implies a poor environmental performance.

The Environmental Performance Index is based upon two policy objectives: Environmental Health, which measures threats to human health, and Ecosystem Vitality, which measures natural resources and ecosystem services. A country's EPI score is ranked from 0 to 100 . High scores indicate good environmental performance. However, to be consistent with the other indicators' convention of higher values representing poor environmental performance, we have inverted the scores for the purpose of this analysis.

More details about these indices and indicators and their calculation are given in the supplementary document attached to this article. Here it should be highlighted that there are obvious epistemological differences between these indices and indicators. Five of the indicators are quite focused on environmental aspects (Material, Carbon and Ecological Footprints and Domestic Material Consumption and $\mathrm{CO}_{2}$ emissions), whereas the Material Intensity includes a very strong economic element (the GDP denominator) and the Environmental Performance Indicator brings in a strong element of social desirability.

\section{Comparing the different measures of environmental sustainability with each other, and with measures of economic growth}

It is reasonable to expect that composite measures of environmental sustainability should generally agree with each other, or, at the very least, not contradict each other. They may have different emphases and constructions, but the thing that they are measuring, sustainability, the impact of people on the environment, and its multiple facets, should be producing a similar sort of signal.

This is not the case. Rather we have two groups of measures. There is agreement within each group, and disagreement between them. Large Material or Carbon footprints are positively related to large Ecological footprints and both to Domestic Material Consumption and $\mathrm{CO}_{2}$ Emissions (Table 2, Figure 1e and Figure 1f ). But the measures of material consumption and measures of environmental performance are inversely correlated (Figure 1a). They oppose each other. Large footprints (either material, carbon or ecological) tend to coincide with good performance as shown by Environmental Performance Index values. This means that, paradoxically, having a high material, carbon or ecological impact is good for the environment according to this Index. On the other hand, having low footprints - either material, carbon or ecological - seems to be bad for the environment according to this Index. This is particularly true for low-income countries. Figure 1 plots indicators and indices

tons per hectare) from which it was harvested, or where its waste material was absorbed. The number of hectares that result from this calculation are then converted to global hectares using yield and equivalence factors (see the supplementary document). The sum of the global hectares needed to support a person is that person's total Ecological Footprint. According to the Ecological Footprint Glossary, a global hectare is a biologically productive hectare with world average biological productivity for a given year. Global hectares are needed because different land types have different productivities. A global hectare of, for example, cropland, would occupy a smaller physical area than the much less biologically productive pastureland, as more pasture would be needed to provide the same biocapacity as one hectare of cropland. Because world productivity varies slightly from year to year, the value of a global hectare may change slightly from year to year.

${ }^{3} \mathrm{CO}_{2}$-eq is a metric measure used to compare the emissions from various greenhouse gases based on their global-warming potential (GWP), by converting amounts of other gases to the equivalent amount of carbon dioxide with the same global warming potential. Carbon dioxide equivalents are commonly expressed as million metric tons of carbon dioxide equivalents, abbreviated as MMTCDE. Here we will use the unit of metric tons per capita ( $\mathrm{Mt} \mathrm{CO}_{2}$-eq per capita). 
against others, grouped by income quartiles. Although low-income countries (orange bubbles) had the lowest per-capita footprints (material, carbon and ecological), none of them had an Environmental Performance Index score below 45. Similarly, Material Intensity is also negatively correlated with footprints, $\mathrm{DMC}^{\mathrm{and}} \mathrm{CO}_{2}$ emissions. In practice this means that countries with low levels of Material Intensity show also large footprints (see Figure 1b).

\begin{tabular}{|c|c|c|c|c|c|c|c|}
\hline & $\begin{array}{c}\text { Material } \\
\text { Footprint }\end{array}$ & $\begin{array}{c}\text { Domestic } \\
\text { Material } \\
\text { Consumption }\end{array}$ & $\begin{array}{c}\text { Material } \\
\text { Intensity }\end{array}$ & $\begin{array}{c}\text { Environmental } \\
\text { Performance } \\
\text { Index }\end{array}$ & $\begin{array}{c}\text { Ecological } \\
\text { Footprint }\end{array}$ & $\begin{array}{c}\text { Carbon } \\
\text { Footprint }\end{array}$ & $\begin{array}{c}\text { Co2 } \\
\text { Emission } \\
\text { (territorial) }\end{array}$ \\
\hline $\begin{array}{c}\text { Material } \\
\text { Footprint }\end{array}$ & 1 & & & & & & \\
\hline $\begin{array}{c}\text { Domestic } \\
\text { Material } \\
\text { Consumption }\end{array}$ & $0.79^{* *}$ & 1 & & & & & \\
\hline $\begin{array}{c}\text { Material } \\
\text { Intensity }\end{array}$ & $-0.67^{* *}$ & $-0.38^{* *}$ & 1 & & & & \\
\hline $\begin{array}{c}\text { Environmental } \\
\text { Performance } \\
\text { Index }\end{array}$ & $-0.77^{* *}$ & $-0.63^{* *}$ & $0.77^{* *}$ & 1 & & & \\
\hline $\begin{array}{c}\text { Ecological } \\
\text { Footprint }\end{array}$ & $0.84^{* *}$ & $0.83^{* *}$ & $-0.65^{* *}$ & $-0.74^{* *}$ & 1 & & \\
\hline $\begin{array}{c}\text { Carbon } \\
\text { Footprint }\end{array}$ & $0.88^{* *}$ & $0.81^{* *}$ & $-0.72^{* *}$ & $-0.77^{* *}$ & $0.90^{* *}$ & 1 & \\
\hline $\begin{array}{c}\text { Co2 Emission } \\
\text { (territorial) }\end{array}$ & $0.79^{* *}$ & $0.84^{* *}$ & $-0.60^{* *}$ & $-0.67^{* *}$ & $0.88^{* *}$ & $0.94^{* *}$ & 1 \\
\hline
\end{tabular}

Table 2: Spearman's rank Correlation matrix between all measurements. As some of the relationships between the variables are not linear, following Hauke and Kossowski (2011), we have computed a Spearman's rank correlation matrix. We have also computed a matrix correlation according to the best fit curve. More detail information at the Supplementary Document. Source: Own table base on Environmental Performance Index database, UN Environment International Resource Panel, Environment Live / Global Material Flows and Global Footprint Network, Eora Miro Database, World Bank database. ** significant at $99 \%$ level $\mathrm{N}=155$ countries.

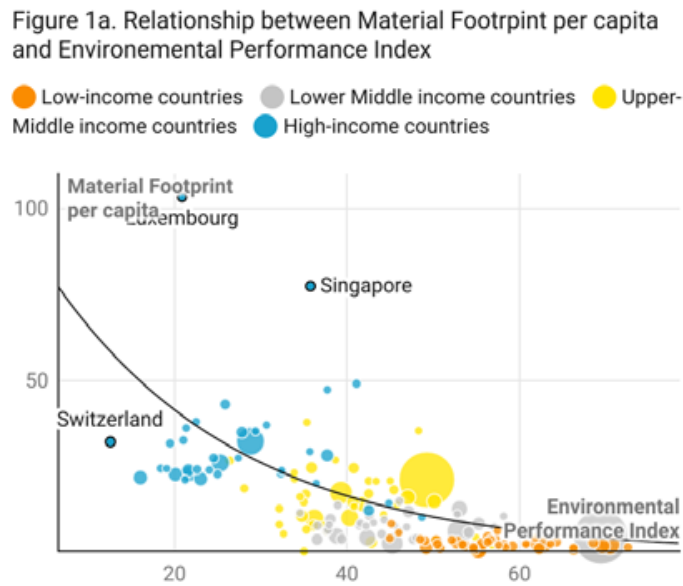

Chart: Requena-i-Mora \& Brockington (2021) • Source: Global Material Flows and Environmental Performance Index · Created with Datawrapper

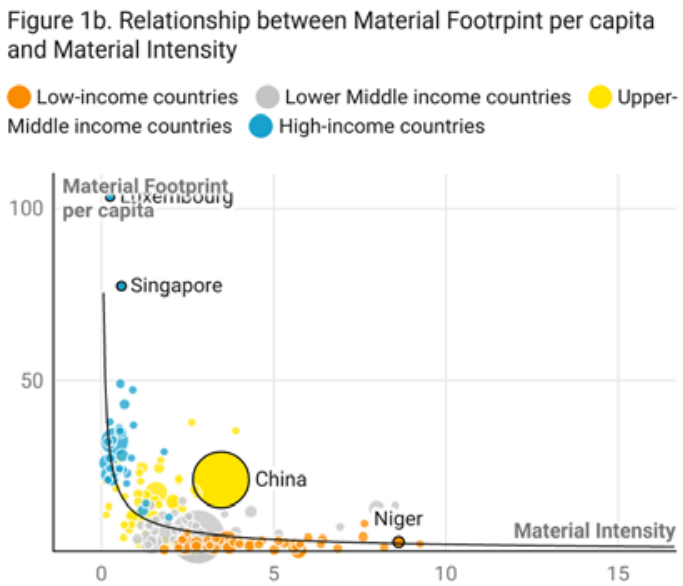

Chart: Requena-i-Mora \& Brockington (2021) · Source: Global Material Flows . Created with Datawrapper 
Figure 1c. Relationship between Material Intensity and Environemental Performance Index

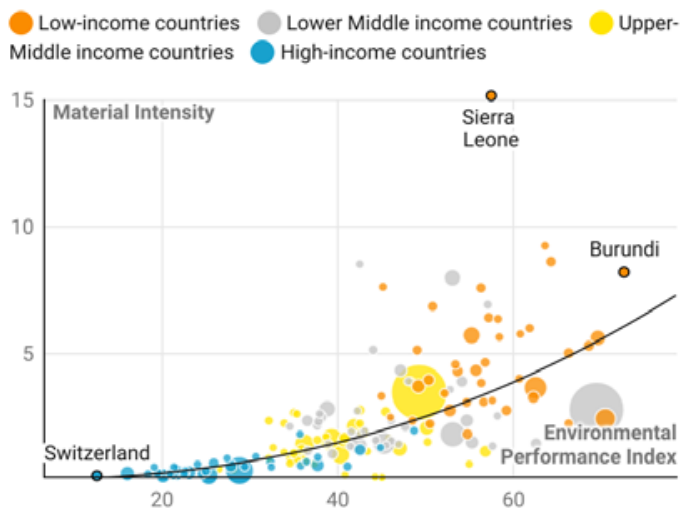

Chart: Requena-i-Mora \& Brockington (2021) $\cdot$ Source: Global Material Flows and Environmental Performance Index · Created with Datawrapper

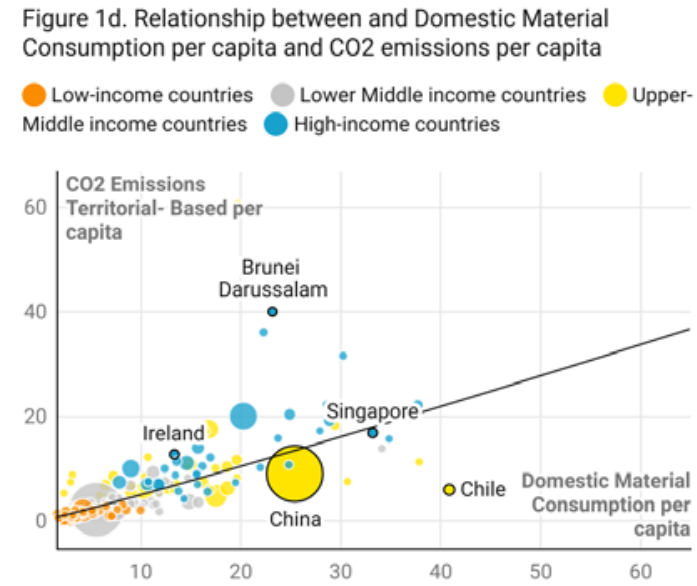

Chart: Requena-i-Mora \& Brockington (2021) - Source: Global Material Flows . Created with Datawrapper
Figure 1e. Relationship between Material Footrpint per capita and Domestic Material Consumption per capita

Low-income countries Lower Middle income countries UpperMiddle income countries High-income countries

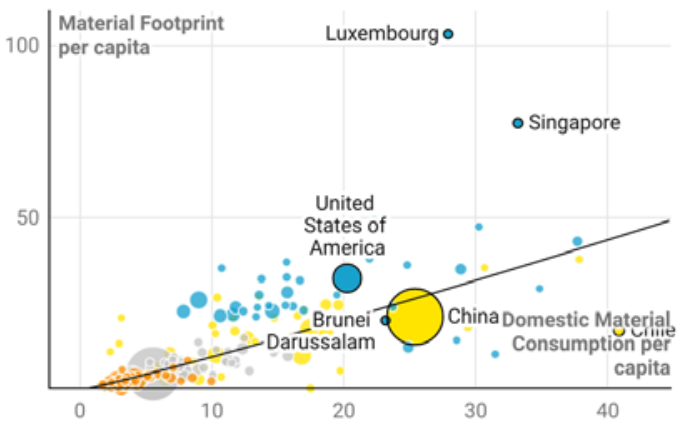

Chart: Requena-i-Mora \& Brockington (2021) · Source: Global Material Flows · Created with Datawrapper

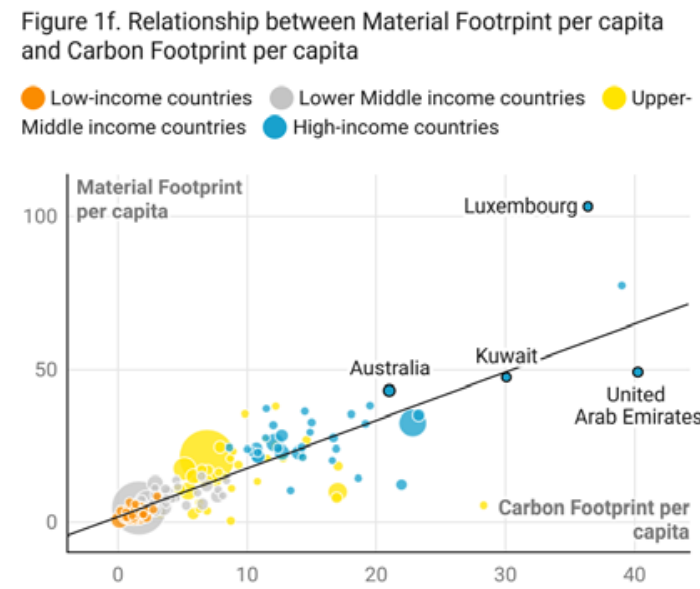

Chart: Requena-i-Mora \& Brockington (2021) $\cdot$ Source: Global Material Flows and EORA MRIO $\cdot$ Created with Datawrapper

Figure 1. Comparing all the environmental sustainability measures against each other. Grouped by income (GDP per capita PPP). The size of each bubble is proportionate to population. The rest of the figures are included in the the Supplementary Document to this article. We have also included links for an interactive visualization of these figures.

Figure 1a: https://datawrapper.dwcdn.net/Df5ri/2/; Figure 1b: https://datawrapper.dwcdn.net /Di4oj/4/; Figure 1c: https://datawrapper.dwcdn.net/MsgPl/4/; Figure 1d: https://datawrapper .dwcdn.net/R6nyM/7/; Figure 1e: https://datawrapper.dwcdn.net/C8v4T/4/ ; Figure 1f: https:// datawrapper.dwcdn.net/MY38G/5/

$\mathrm{N}=155$ countries; all the correlations are significant at 99\% level of confidence. Source: Own figure based on Environmental Performance Index database, UN Environment International Resource Panel, Environment Live / Global Material Flows and Global Footprint Network and EORA database 
We found similar contradictory results when we analyzed the relationships between all sustainability measurements and GDP (Figure 2 and Table 3). The Environmental Performance Index and Material Intensity indices vary negatively with GDP (Figure 2a and $2 \mathrm{~b}$ and Table 3). Both measurements indicate that the countries that are performing well in environmental terms are the richest ones, using resources most efficiently to produce high levels of GDP. The other measures of environmental sustainability all get worse as GDP increases. Domestic Material Consumption, CO2 emissions, the Material, Carbon and Ecological Footprints all increase as GDP increases (Figures 2c and 2d and Figures 2 in the Supplementary Document).

\begin{tabular}{|c|c|c|c|c|}
\hline & $\begin{array}{l}\text { Spearman's } \\
\text { rank } \\
\text { correlation }\end{array}$ & $\begin{array}{l}\mathbf{R}^{2} \text { best fit } \\
\text { curve }\end{array}$ & Best fit model & $\begin{array}{c}\text { Relationships } \\
\text { between the } \\
\text { indicator and } \\
\text { GDP } \\
\end{array}$ \\
\hline Material Footprint & $0.87 * *$ & $0.73^{* * \text { Linear }}$ & $\begin{array}{c}y=a+b x \\
b>0 \quad \text { significant } \\
\text { Positive linear relationship }\end{array}$ & $\begin{array}{c}\text { Material Footprint } \\
\text { increase linearly with } \\
\text { GDP }\end{array}$ \\
\hline $\begin{array}{l}\text { Domestic Material } \\
\text { Consumption }\end{array}$ & $0.79 * *$ & $0.47^{* * \log }$ & $\begin{array}{c}\qquad \begin{array}{c}y=a+b \log x \\
b>0\end{array} \\
\text { Positive Linear-logarithmic relationship }\end{array}$ & $\begin{array}{c}\text { Diminishing } \\
\text { Domestic Material } \\
\text { Consumption with } \\
\text { higher GPD per capita }\end{array}$ \\
\hline Material Intensity & $-0.83 * *$ & $0.57^{* * \log }$ & $\begin{array}{c}y=a+b \log x \\
b<0 \text { significant } \\
\text { Negative Linear-logarithmic relationship }\end{array}$ & $\begin{array}{c}\text { As GDP rises } \\
\text { Material Intensity } \\
\text { decreases }\end{array}$ \\
\hline $\begin{array}{c}\text { Environmental } \\
\text { Performance Index }\end{array}$ & $-0.83 * *$ & $0.67^{* * \log }$ & $\begin{array}{c}y=a+b \log x \\
b<0 \\
\text { Negative Linear-logarithmic relationship }\end{array}$ & $\begin{array}{l}\text { As GDP rises the } \\
\text { Environmental } \\
\text { Performance Index } \\
\text { decreases }\end{array}$ \\
\hline Ecological Footprint & $0.89 * *$ & $0.73^{* *}$ Quadratic & $\begin{array}{c}y=a+b_{1} X+b_{2}(x-\bar{x})^{2} \\
b_{2}<0 \text { significant } \\
\text { Second grade polynomial function } \\
\text { Inverted U shape* }\end{array}$ & $\begin{array}{c}\text { Ecological Footprint } \\
\text { increases in the initial } \\
\text { levels of GDP to } \\
\text { decrease later on, after } \\
\text { a certain point of } \\
\text { return. }\end{array}$ \\
\hline Carbon Footprint & $0.93 * *$ & $0.80^{* * \text { Linear }}$ & $\begin{array}{c}y=a+b x \\
b>0 \text { significant } \\
\text { Positive linear relationship }\end{array}$ & $\begin{array}{c}\text { Carbon Footprint } \\
\text { increase linearly with } \\
\text { GDP }\end{array}$ \\
\hline $\begin{array}{c}\mathrm{CO}_{2} \text { Emission (production- } \\
\text { based) }\end{array}$ & $0.88^{* *}$ & $0.45^{* * \text { Quadratic }}$ & $\begin{array}{c}\qquad y=a+b_{1} X+b_{2}(x-\bar{x})^{2} \\
b_{2}<0 \text { significant } \\
\text { Second grade polynomial function } \\
\text { Inverted U shape* }\end{array}$ & \begin{tabular}{|c|} 
CO2 Emission \\
(production-based) \\
increases in the initial \\
levels of GDP to \\
decrease later on, after \\
a certain point of \\
return.
\end{tabular} \\
\hline
\end{tabular}

Table 3: Relationships with all measurements and GDP per capita ** significant at 99\% level $\mathrm{N}=155$ countries. $* b_{2}<0$ and the peak of income (peak of income $=\bar{x}-\left(\frac{b_{1}}{2 b_{2}}\right)$ ) is within the range of the incomes existing in the sample: otherwise, only one half of the inverted $U$ has been observed. Working for the best-fits curve is supplied in the Supplementary Document. Source: Own table base on Environmental Performance Index database, UN Environment International Resource Panel, Environment Live / Global Material Flows and Global Footprint Network, Eora Miro Database, World Bank database.

However, there are interesting differences in the precise nature of their relationships with GDP. There are signs that GDP has a non-linear influence on Domestic Material Consumption, $\mathrm{CO}_{2}$ emissions (productionbased) and the Ecological Footprint (see Table 3 and Figures 2 in the Supplementary Document). The best-fit curve for the relationship between Domestic Material Consumption and GDP per capita is positive linearlogarithmic, suggesting diminishing resource use or emissions with higher GDP per capita. The best fit curves for the relationship between $\mathrm{CO}_{2}$ emissions and GDP and also Ecological Footprint and GDP are second-grade 
polynomials and negative square coefficients (drawing an inverted $U$ shape) meaning that various environmental problems will get worse as economies grow, but then decline as economic activity and environmental governance act to clean up and repair current damage. The only exception is the Carbon and Material Footprints, which increase linearly with GDP per capita.

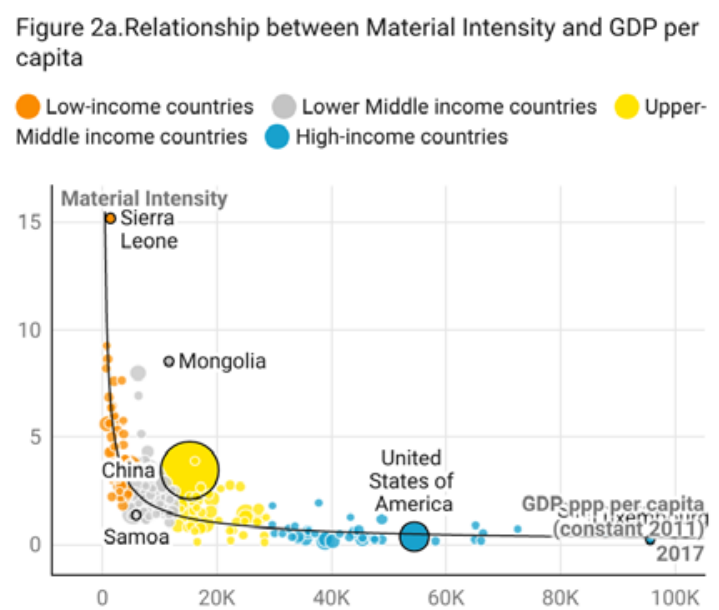

Chart: Requena-i-Mora \& Brockington (2021) • Source: Global Material Flows database and The World Bank · Created with Datawrapper

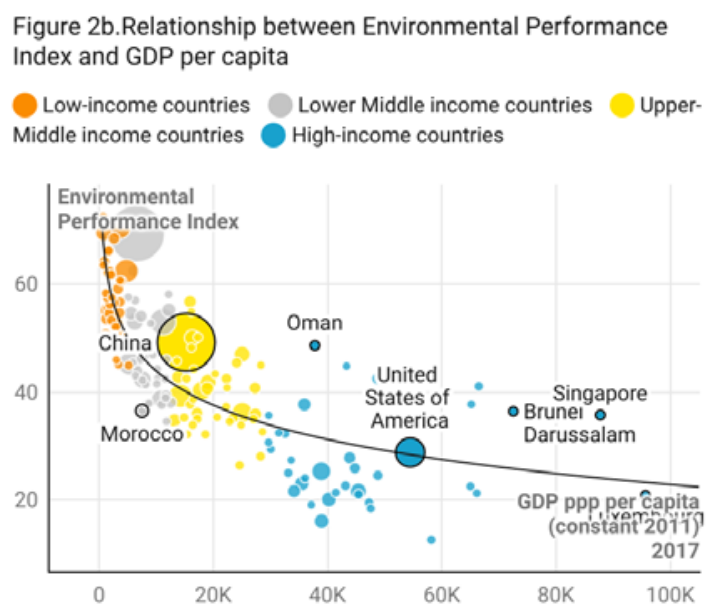

Chart: Requena-i-Mora \& Brockington (2021) - Source: World Economic Forum and The World Bank · Created with Datawrapper
Figure 2c. Relationship between Domestic Material Consumption and GDP per capita

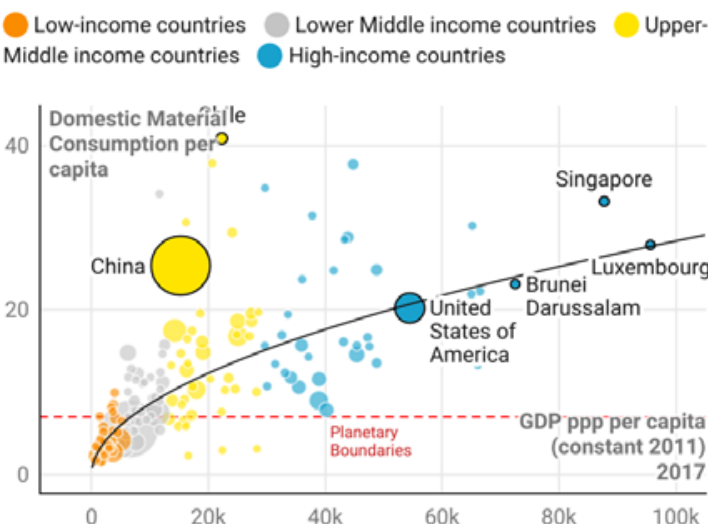

Chart: Requena-i-Mora \& Brockington (2021) · Source: Global Material Flows and The World Bank . Created with Datawrapper

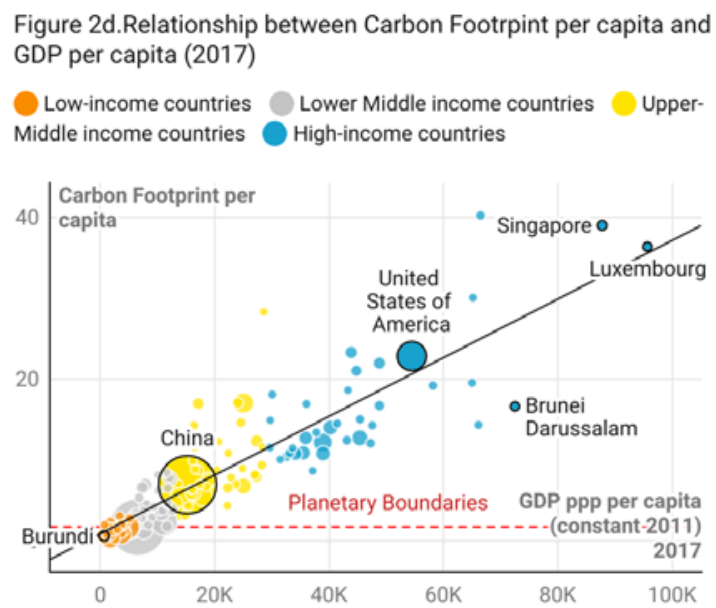

Chart: Requena-i-Mora \& Brockington (2021) • Source: EORA MRIO and The World Bank $\cdot$ Created with Datawrapper

Figure 2: Comparing all the measures with GDP per capita. The rest of the figures are included at the Supplementary Document of this article. see Supplementary Figures 2. N=155 countries; all the correlations are significant at $99 \%$ level of confidence. Interactive figures: Figure 2a: https://datawrapper.dwcdn.net/4at3U/4; Figure 2b: https://datawrapper.dwcdn.net/G4tyS/4/ Figure 2c: https://datawrapper.dwcdn.net/M54qu/5/; Figure 2d: https://datawrapper.dwcdn. net/l2ShZ/1/ Source: Own figures based on Environmental Performance Index database UN Environment International Resource Panel, Environment Live/ Global Material Flows, EORA database and World Bank Database and World Bank database 


\section{What drives the differences in the relationship between the indices, indicators and economic growth?}

The differences between these measures of environmental sustainability are stark. It would be hard to derive a coherent sustainability agenda from them to establish which countries should make what changes even, distinguishing between the richest or the poorest nations. In order to forge a robust sustainability agenda, we have to understand what drives these differences. It is, we argue, through examining difference that the theories informing different "mash-up" indices and indicators can best be understood. For us to appreciate them properly we must first take a detour, following Joan Martinez-Alier's work, into the different approaches to sustainability that these indices in fact serve.

In particular, understanding the results of the Environmental Performance Index and Material Intensity Index (which improve with GDP) will help us to understand calls for a transition to a "green growth" pathway (e.g. UNEP 2011; OECD 2011; World Bank 2012) in which growth continues but is somehow decoupled from key material inputs. The other indices help to explain a rather different set of proposals that push for a focus away from economic growth (e.g. Georgescu-Roegen 1971; Martinez-Alier 2009a; Latouche 2006; Garcia 2004; Taibo 2009 and Jackson 2009 among others). Following Garcia (2006), the discussion can be summed up in two opposing scenarios, that of 'Productive Confidence' and 'Ecological Prevention' (Figure 3).
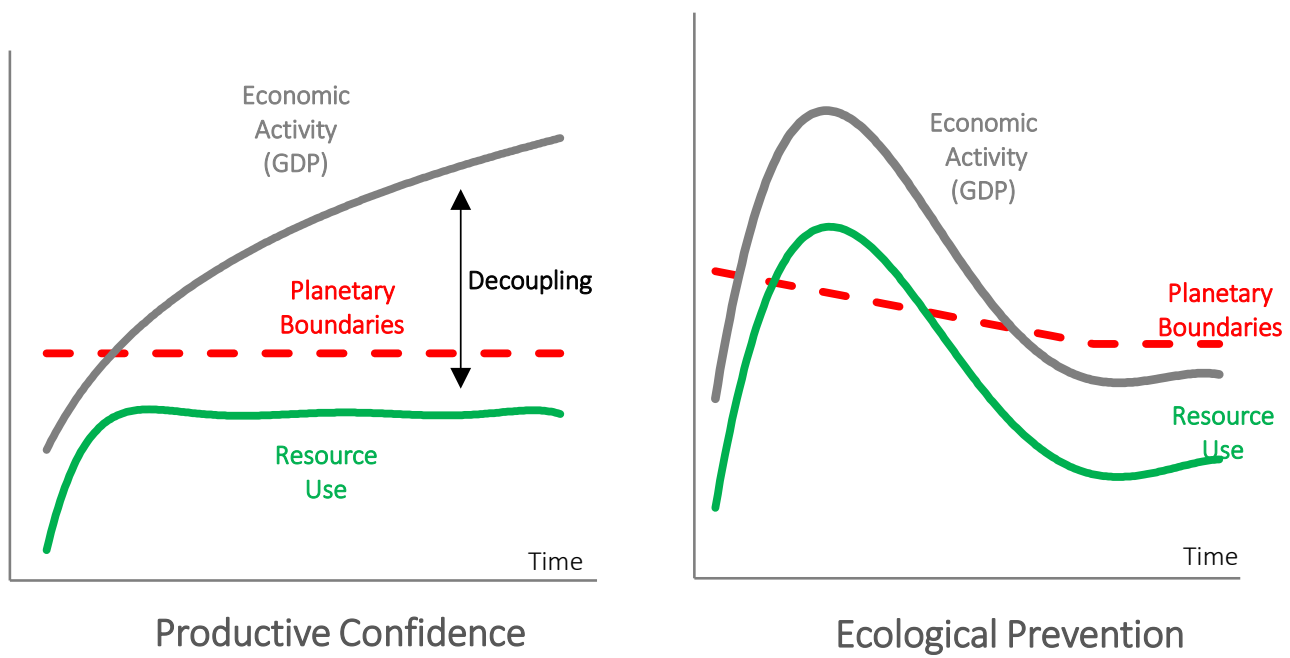

Figure 3. Productive Confidence and Ecological Prevention. Source: Garcia (2006)

\section{Productive Confidence}

The position of Productive Confidence is constituted by an assemblage of positions, as Martinez-Alier (1995a) has shown. These posit the environmental benefits of continued economic growth combined with changes to the way that nature and the environment are perceived and valued, which will result in stronger protection for the natural world.

Two theories underpin this reasoning. First, the Environmental Kuznets curve - based upon "The Kuznets curve" (Kuznets 1950) and used for the first time by Grossman and Krueger 1991 as an Environmental Kuznets Curve). This suggests that various environmental problems (e.g. air / river pollution) will get worse as economies grow, but then decline as economic activity and environmental governance act to clean up and repair current damage. Cleaning up thus becomes a profitable industry, damage is costly, and technology improves to become less damaging (and less expensive). Economic growth is thus ultimately good for the environment. 
Second, the idea of "weak sustainability" (based upon the work of Solow [1957] and Pearce [Pearce and Atkinson 1993]) assumes that sustainability depends on the maintenance of the capital stock, with substitution allowed between different capital forms (Pearce and Atkinson 1993: 104). Weak sustainability thus assumes almost complete substitutability between 'natural' and 'manufactured' capital. For example, a tree plantation that is being cut down to make paper would be sustainable as long as the paper sales generated enough revenue to re-plant and sustain the new plantation. This ensures that there is a constant flow of capital, and none is lost. In fact, capital is gained in the form of the paper product being sold (Simko et al. 2014). According to such perspectives, economic growth is sustainable if it saves more than the combined depreciation of the two forms of capital. Hence, manufactured capital can growth indefinitely and substitute natural capital - although it is a moot point what sort of 'environment' is created and conserved.

The implication of the Environmental Kuznets curve and the idea of weak sustainability is that the material economy can grow without plundering natural resources, because technical improvements and substitutions allow decoupling to take place. As Jackson puts it "Economic output becomes progressively less dependent on material throughput. In this way, it is hoped, the economy can continue to grow without breaching ecological limits" (Jackson 2009: 67, see also figure 3).

Progressive decline of 'material throughput' is also known as decoupling - the attempt to allow economic growth to occur without attendant growth in material inputs. But it is necessary to distinguish between relative and absolute decoupling. Relative decoupling refers to a decline in the ecological intensity per unit of economic output. In this situation, resource uses decline relative to the GDP. But they do not necessarily decline in absolute terms. Impacts may still increase, but at a slower pace than growth in GDP. The situation in which resource impacts decline in absolute terms is called 'absolute decoupling.'

Those who advocate for Productive Confidence would argue that some countries, especially the most mature economies, are experiencing real (absolute) decoupling. This decoupling between economic growth and resource consumption has intensified because of technological improvements, and the shift of economic activity towards services and an information and knowledge economy (Garcia 2006). This perspective is sometimes called 'ecological modernization', because it envisages that economic growth will transform what the economy does to the environment (for the better) (Martinez-Alier 2002).

Productive Confidence is also imbued by three other ideas that hold that nature will be valued better and more effectively - society as a whole will evolve in such a way that continued destruction of valued nature becomes uneconomic and unpopular. These include, first, Inglehart's post-materialist thesis (Inglehart 1977, 1995), which posits that as societies become richer so they seek more amenity value in nature and will come to value the natural world more highly, directing political pressure and entrepreneurial activity towards strong environmental protection. Second, Krutilla's criterion for the valuation of environmental amenities (Krutilla 1967), which proposes to modify cost-benefit analyses to allow environmental amenities to retain, or even increase their value over time. Krutilla observed that economic discounting practices tended to devalue the long-term contribution of environmental amenities, and he sought to counteract that tendency. Third and finally, Hirsch's notions of "positional goods" (Hirsch 1976) which distinguishes between two categories of goods. There are material goods whose consumption generates utility because of their intrinsic characteristics. This kind of good can grow indefinitely by technological advances. There are also positional goods, whose intrinsic qualities are scarce, and by virtue of that scarcity provide social status. Where particular environments or places acquire value because of their beauty (and especially if that beauty is spoilt elsewhere) then society will move to protect them because that beauty is now valuable. This can either be through things like property prices, or through planning legislation which moves dirty industries to poor neighborhoods (for which see the huge literature on 'environmental justice' for instance: Bullard, 1996; Martinez-Alier, 1997; Apostolopoulou and Cortes-Vazquez, 2018).

These three ideas, post-materialism, Krutilla's criterion and positional goods combine to promote a particular form of environmentalism that is characteristic of wealthy societies. It is both produced by, and justifying of, the economic growth that creates it. It assumes an elastic supply of material goods and that technological change and economic growth can reduce unwelcome environmental change. These ideas theoretically inform some of the indices and indicators analyzed here. 


\section{Ecological Prevention}

The views described as Ecological Prevention in Figure 4 include the idea that resource use has already exceeded wise limits, and that dematerialization of economic growth is challenging. Some also insist that levels of resource use must shrink, after a reduction in economic growth and resource use (Garcia 2006). There is much debate between those who think that we need to reduce economic growth and resource use, i.e. degrowth, and those who advocate for stabilizing these variables instead; i.e. Steady State economics.

Economic degrowth ideas first appeared during the mid- to late-1970s. The main idea behind the concept challenges the "growthmania" (Georgescu-Roegen 1977: 270) of orthodox economists and has latterly been defined as an equitable downscaling of production and consumption that increases human well-being and enhances ecological conditions at the local and global level, in the short and long-term (Schneider et al., 2010). Some degrowth proponents would add that such downscaling has to assure that society's throughput — resource use and waste — stays within safe planetary boundaries ${ }^{4}$ (Kallis 2011; Schneider et al. 2010).

Contrary to Georgescu-Roegen, Daly (1973) argues that attaining a sustainable state of the human economy is possible through a transition to a stationary or steady state. Swayed by John Stuart Mill's description of a stationary state and based on the thermodynamic world view of Georgescu-Roegen, Daly developed the concept of a desirable zero-growth economy (Kerschner 2010). However, advocates of a Steady State economy increasingly call for a period of degrowth in the transition to a steady state (Farley, 2014). A growing number of studies suggest that the global economy has exceeded critical planetary boundaries (O'Neil et al. 2019; Rockström et al. 2009). According to Farley (2014), for those who promote a Steady State economy, the question is no longer when to stop economic growth, but rather how much degrowth is necessary before we transition to a steady state.

In contrast to weak sustainability, which assumes complete substitutability between different capital stocks, these theories do not presume such substitutability is possible, meaning that all-natural capital must be conserved. For proponents of strong sustainability, the substitutability of manufactured for natural capital is seriously limited by specific characteristics of the latter, such as irreversibility, uncertainty, and the existence of critical components of natural capital which make a unique contribution to welfare (Costanza and Daly, 1992).

Behind notions of Ecological Prevention is the assumption that the growth of the material economy is linked to increased flows of energy and materials (Steinberger et al. 2013) and that these imply a heavier, negative environmental impact on ecosystems. High use of energy and material mostly derives from the wealthy countries. Wiedmann et al. (2015) has pointed out that "a number of studies have identified affluence, along with other factors, as a key driver for consumption based indicators, such as land (Weinzettel et al. 2013), carbon (Hertwich and Peters 2009), energy (Lenzen et al. 2006), ecological footprints (Wiedmann et al. 2006), and water footprints (Lenzen and Foran, 2001), as well as resource use (Schand and Turner, 2009)" (Wiedmann et al. 2015: 6273). More recently, Wiedmann et al. (2020) posited that the wealthiest 0.54 percent, about 40 million people, are responsible for 14 percent of lifestyle-related greenhouse gas emissions, while the bottom 50 percent of income earners, almost 4 billion people, only emit around 10 percent. For these reasons economic growth is ultimately bad for the environment.

\footnotetext{
${ }^{4}$ The planetary boundaries jointly define a 'safe operating space', within which it is argued the relatively stable conditions of the Holocene may be maintained (Rockström et al. 2009). Some degrowth proponents have criticized the concept of planetary boundaries. According to them, this concept is underpinned by a faith in factual information presented by scientists as unquestionable truths, without questioning the political system into which that information enters (Smith-Spash, 2014). They argue that all data suffer from uncertainty and some more than others, some of the indicators are weak, the proposed boundaries are arbitrary and ignore feedback loops, and the focus is global but several of the systems covered are more interesting to look at from a local or regional level (e.g. freshwater use). Looking at sources rather than sinks may be more useful to deal with issues of resource scarcity (ibid.). Some have claimed the concept is a social construction, meaning the limits are not only biophysical, but also political as they depend on "perceptions of risk, on public debate and powerful lobby groups, and on international political power" (Raworth 2012: 12). Alternatives have been suggested such as building stable institutions that guarantee a safe transition and a co-evolution of natural and social systems at planetary scale (Biermann 2012, p.7), rather than planetary boundaries (Biermann 2012) or moving beyond a focus on biophysical limits and global scale analyses, towards solution-oriented research from household to global scales (DeFries et al. 2012).
} 
The idea that economic growth must result in an increase in resource use, making decoupling difficult, is captured in Jevons' Paradox (1865) or the 'rebound effect.' Jevons' Paradox states that an increase in resource efficiency leads to an absolute increase in the use of that resource, as a falling price brings formerly unprofitable resource-consuming processes into production, and rising income drives consumption (Kemps-Benedict 2018). For example, efficiency gains in internal combustion engines have help made private car transportation effective and affordable. This ubiquity of private car transport has in turn driven up car ownership, and the extensive reconfiguration of cities that now rely on the use of private cars. This scale modification of the system of needs now results in dramatically higher energy consumption from the transport sector (Parrique et al. 2019). So the benefits of increased eco-efficiency can easily be nullified or even can increase the total use of natural resources consumed (Martinez-Alier 2014).

To sum up, in the Ecological Prevention scenario, relative decoupling could be a signal of improvement in the efficiency of the economy, but it does not necessarily mean we are using fewer materials (or emitting fewer pollutants) overall. From this perspective, what is needed is an absolute decrease, where resource use (or emissions) declines in absolute terms and on a global scale, even as economic output continues to rise (Jackson 2017).

\section{What types of theoretical assumptions are informing the index and indicators?}

As we have mentioned, the Environmental Performance Index and Material Intensity scores improve as GDP rises. But why do wealthy countries appear to perform well with respect to Environmental Performance Index and Material Intensity but are the worst countries in terms of their footprints? In this section we explore how the theories we have described above inform different indices. In the account below 'theories of productive confidence' refers to all those theories which show how environmental sustainability can improve with economic growth, whereas 'theories of Ecological Prevention' hold that economic growth can harm the environment.

\section{The Environmental Performance Index}

The negative relationship between GDP per capita and the Environmental Performance Index score shows that economic growth is "good for the environment because it will provide the means for cleaning up the environment" (Martinez-Alier 1995a: 1). Note that we have inverted the scores for the purpose of this analysis so that higher values indicate poor performance. Improved quality of air, water and sanitation are all captured in this index. As predicted in the World Bank's World Development Report 1992 (IBRD 1992), it seems that "as incomes rise, the demand for improvements in environmental quality will increase, as will the resources available for investment" (p. 39). Similarly, the main message of the Brundtland report was that poverty is the main cause of environmental degradation. Hence, economic growth, renamed as sustainable development, is a remedy for both poverty and environmental degradation (Guha and Martinez-Alier 1997). Countries with large footprints and high economic capacity can therefore invest in reducing pollution stresses, improving resource efficiency and addressing some of the consequences of their high natural resource consumption rates. The everyday environment needed for subsistence presents no problems for high-income countries and environmental amenity becomes a luxury.

The 2018 Environmental Performance Index ranks 180 countries on 24 performance indicators across ten issue categories covering environmental health and ecosystem vitality. According to the Environmental Performance Index's developers, the Index bridges a tension between two fundamental dimensions of sustainable development: (1) environmental health, which rises with economic growth and prosperity, and (2) ecosystem vitality, which comes under strain from industrialization and urbanization. However, as we can see in Figure 4, western countries do not experience the aforementioned tension and show a good performance in both Ecosystem Vitality and Environmental Health (higher values for both categories indicate poor performance). Such a relation could be accounted for by Environmental Kuznets curves. Western countries are at the bottom-right corner (Figures 4) not only because they are rich, but also because they are post-industrial economies that passed through a process of modernization that has entailed the relocation and cleaning of the most polluting industries. 

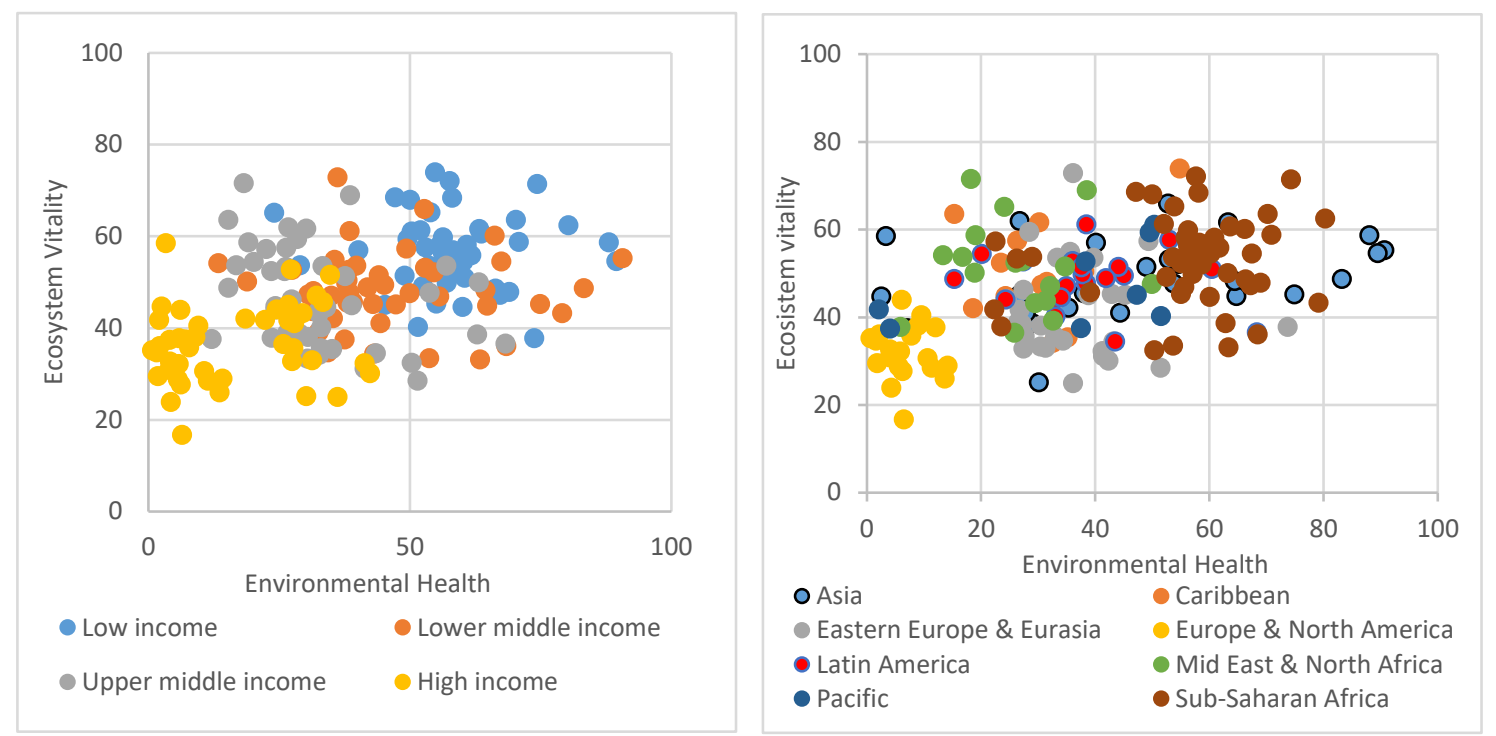

Figure 4: Relationships between Ecosystem Vitality and Environmental Health. Source: Own figure based on Environmental Performance Index database

Thus, according to the Environmental Performance Index, economic growth is good for the environment and the future that the Index envisions is close to the Green Growth or Productive confidence scenario.

\section{Domestic Material Consumption, Material Footprint and Material Intensity}

Indicators of material consumption measure extraction and use of biomass, minerals, fossil fuels and construction materials. Such measurements are key indicators in that they pertain to a broad range of ecological concerns, including deforestation, meat consumption, overfishing, greenhouse gas emissions and environmental damage due to mining (Hickel 2018). Nevertheless, behind these three indicators we found very different types of environmentalist thinking. We summarize in Figure 6 the theoretical assumptions that underline these measurements. The Material Footprint per capita shows a strong relationship between the use of materials and wealth - as the proponents of the 'environmentalism of the poor' and in general the Ecological Prevention scenario (Figure 3) are claiming - while the Domestic Material Consumption per capita shows that as the economy grows, initially the environment suffers but eventually the relationship between the environment and the economy improves - as the Environmental Kuznets Curve hypothesis proposes. In fact, Domestic Material Consumption indicates that high-income countries are facing a relative and, in some cases, an absolute decoupling, which is consistent with green growth (Steinberger et al. 2013, Giljum et al. 2014, Wieldmann et al. 2015, Hickel and Kallis 2019).

However, both Material Footprint and Domestic Material Consumption, when measured against a specific planetary boundary ${ }^{5}$, indicate that the majority of the countries analyzed have transgressed such boundaries. Not even $40 \%$ of the analyzed countries are within the per capita boundary for these indicators. Hence, these indices support those in the Ecological Prevention school (Figure 4) who argue that planetary boundaries have been overstepped and so many countries, especially the wealthy ones (see Figures 2), should adopt degrowth strategies.

\footnotetext{
${ }^{5}$ For material footprint and Domestic Material Consumption, Bringezu et al. (2015) uses a planetary boundary of 50 billion tons of materials per year. Dividing this by 7,509 billion people in 2017 gives us 6.7t per person per year (Hickel 2020).
} 


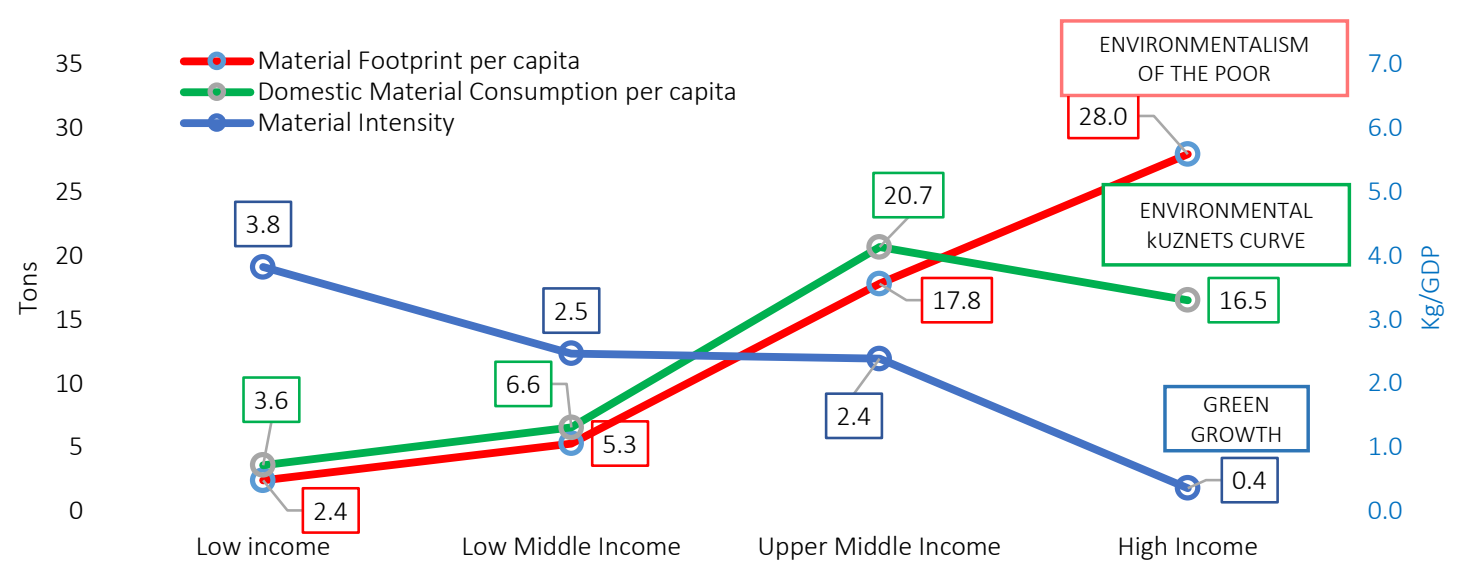

Figure 5: Material Footprint per capita, Domestic Material consumption per capita and Material Intensity grouped by countries level of income (2017). N=155 countries; countries grouped by quartile of income GDP 2017 PPP-2011/cap. Source: Own figure based on UN Environment International Resource Panel, Environment Live / Global Material Flows

Finally, Material Intensity show what a green growth scenario looks like (Figure 5). Material intensity declines as GDP increases (Figure 2), demonstrating that economic growth is good for the environment. As Green growth theory asserts continued economic expansion is compatible with our planet's ecology, as technological change and substitution will allow us absolutely to decouple GDP growth from resource use (Hickel and Kallis, 2019). Hence, according to Material Intensity, the material economy can grow without plundering natural resources. Indeed, this indicator shows that wealthy countries are decoupling, meaning that there is a decline in the material intensity (or the emission intensity) of economic output, at least in relative terms.

\section{$\mathrm{CO}_{2}$ Emissions and Carbon Footprint}

$\mathrm{CO}_{2}$ emissions are a common indicator for strong sustainability. When comparing production-based $\mathrm{CO}_{2}$ emissions and Carbon Footprint ( $\mathrm{CO}_{2}$ emissions at consumption-based) against GDP per capita, our results show also different theoretical assumptions at work. First, relationships between $\mathrm{CO}_{2}$ emissions (productionbased) and GDP would partially support the Environmental Kuznets Curve hypothesis. In Figure 2 and Figure 6 , we observe that GDP has a lesser influence on $\mathrm{CO}_{2}$ emissions (production-based) than on the Carbon Footprint. Just as the proponents of Environmental Kuznets Curve have theorized, $\mathrm{CO}_{2}$ emissions first rise, and then fall or stabilize with increasing income per capita (Table 3). However, when switching from $\mathrm{CO}_{2}$ emissions to Carbon Footprint, emissions increase linearly with GDP. This second situation would be consistent with the Ecological Prevention scenario which claims that the growth of material economy is linked to increase in the flows of energy and materials (Steinberger et al., 2013) and it implies a heavier negative environmental impact on ecosystems. This difference reflects the fact that the Carbon footprint captures the whole value chain beyond borders, whereas $\mathrm{CO}_{2}$ emissions are restricted to national boundaries. So, a country can appear to reduce its planetary impact using the $\mathrm{CO}_{2}$ emissions measure when it is in fact merely exporting them.

Finally, as can be observed in Figure 2, few of the analyzed countries are within the per capita boundary for $\mathrm{CO}_{2}$ emissions and Carbon Footprint ${ }^{6}$ (24\% of the countries). Hence, as Kallis (2017) emphasized, the emission targets agreed in Paris require a radical reduction of emissions and material extraction, use and disposal. Under this perspective, both $\mathrm{CO}_{2}$ emissions indicators (production-based and consumption-based)

\footnotetext{
${ }^{6}$ Basing their calculations on the goal of limiting global warming to $1.5-2{ }^{\circ} \mathrm{C}$, as emphasized in the 2018 IPCC report, Hickel (2020) established a planetary boundary of 1.7 tons per person per year until 2100. O'Neil, et al. (2018) has also calculated a similar amount basing their calculation on the Paris Agreement (1.61 t CO 2 per capita).
} 
imply degrowth is required. This is particularly true in upper-middle- and high-income countries (see Figures 2 in the Supplementary Document), just as the supporters of the Ecological Prevention (Figure 3) are arguing.

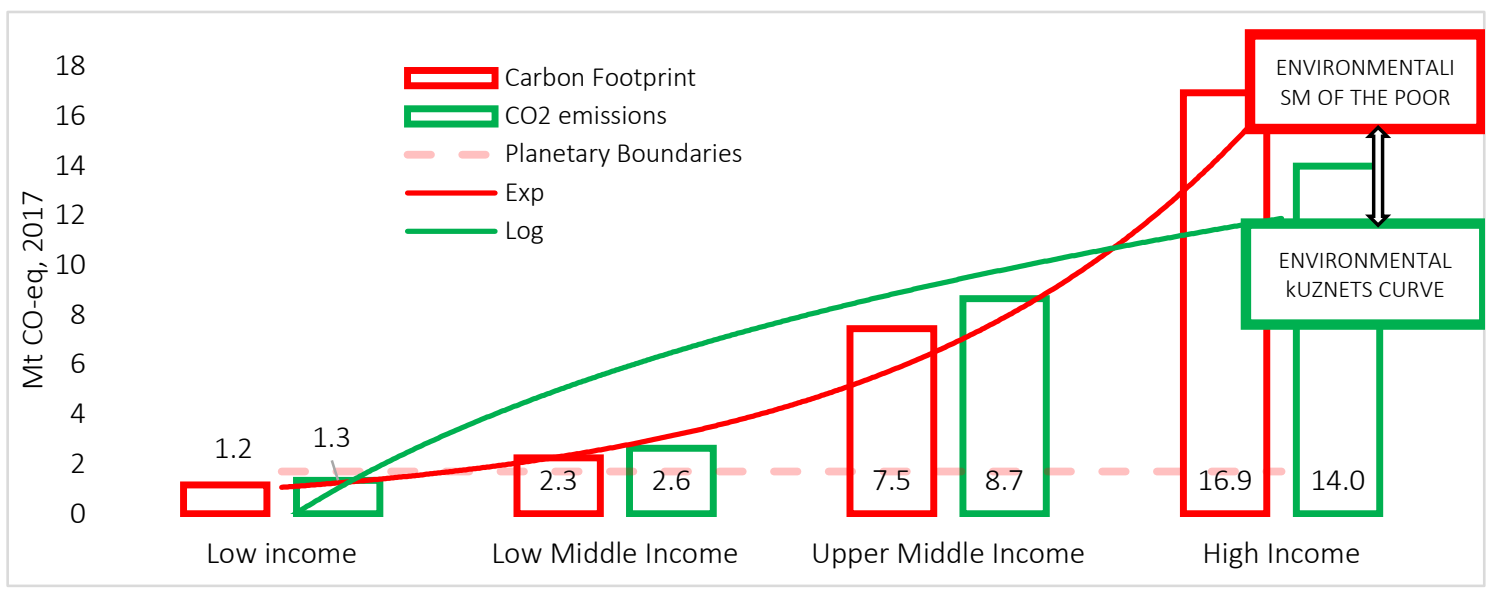

Figure 6: Carbon Footprint per capita and $\mathrm{CO}_{2}$ emissions per capita grouped by countries level of income (2017). N=155 countries; countries grouped by quartile of income GDP 2017 PPP2011/cap. Source: Own figure based on EORA database and World Bank Database

\section{The Ecological Footprint}

The Ecological Footprint measures the ecological assets that a given population requires to produce the natural resources it consumes (including plant-based food and fiber products, livestock and fish products, timber and other forest products, space for urban infrastructure) and to absorb its waste, especially carbon emissions. The relationship between GDP per capita and Ecological Footprint per capita is positive (that is, higher GDP per capita is associated with higher resource use). However, the best-fit curve is quadratic. This shape suggests diminishing resource use with higher GDP per capita. Such result would be consistent with the Productive Confidence scenario.

Nevertheless, grouping Ecological Footprint per capita by national income level reveals the inequality in per country demand for renewable resources and ecological services (see Figure 7). The Ecological Footprint indicator has also calculated the global biocapacity per capita (1.6 g/ha in 2017). Most of the analyzed countries — 74\% — in particular the wealthy ones, are using resources at levels above per capita biophysical boundaries (see Figure 7). Thus, the Ecological Footprint supports the degrowth objective which is to scale down the material and energy throughput of the global economy, focusing on high-income nations with high levels of per capita consumption (Hickel 2019). This indicator is a well-known gauge of strong sustainability, that fits with the assumptions of the Ecological Prevention scenario (Figure 3). As a matter of fact, it is the only one of the analyzed indicators and indices that takes into account the biocapacity of the Earth, i.e. it is the only metric that measures what resources we have and how much we use. Table 4 extends Table 3 to summarize the theoretical implications of each of the selected indicators.

\section{The elephant in Green Growth: devices and tricks that make rich countries look green}

We have explored how particular forms of environmentalism and environmentalist action are represented through assemblages of ideas. We have also analyzed how these ideas are served by indices and indicators that embody their theories and values. However, comparing indices and indicators produces contradictory results. We still do not have definitive answers to the crucial questions that have brought these indices into existence in the first place: What changes are required to save the planet? Should rich countries 
make reductions in consumption and production? Or should poorer countries grow their economies, as fast as sustainably possible, to improve their scores in the Environmental Performance Index and measures of Material Intensity? Is a Green Growth scenario possible or should we move away from economic growth?

We believe that empirical support for Green Growth is, in fact. weak. This is plain when examining the tricks and devices present in some indicators which make rich countries look green. These show flaws in the empirical support for green growth based on business-as-usual scenarios and Productive Confidence scenarios.

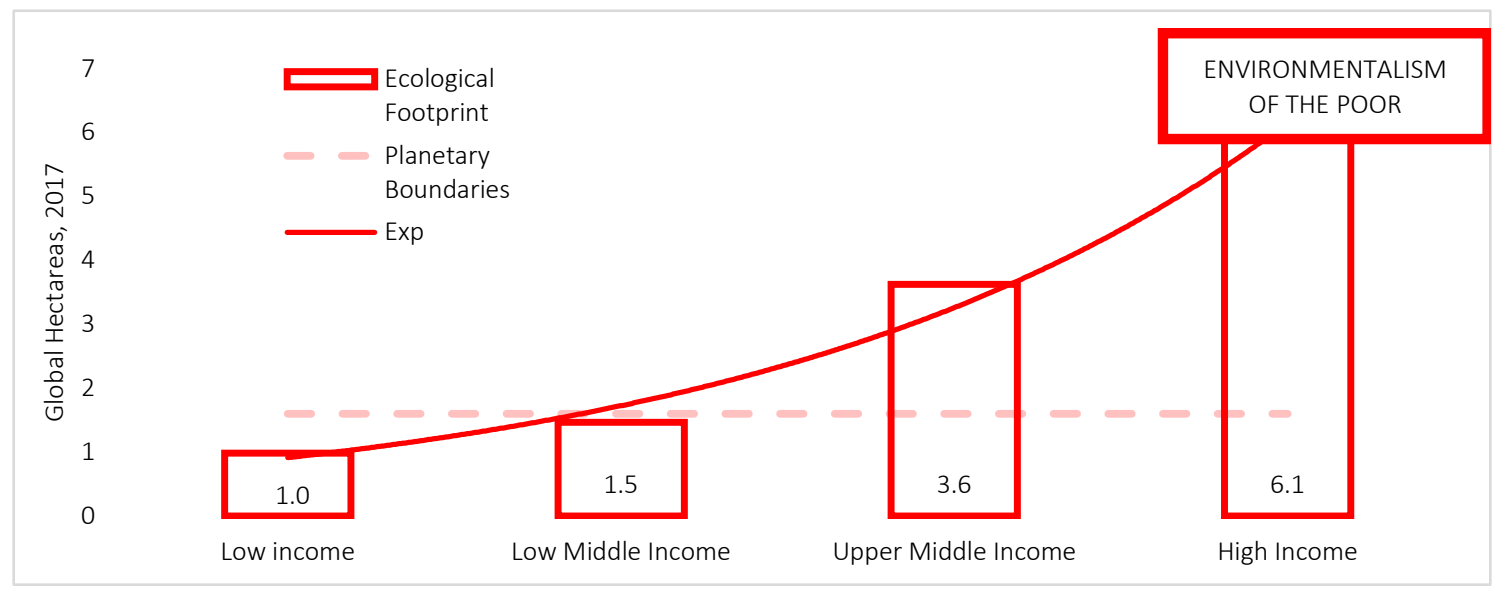

Figure 7: Ecological Footprint per capita and per capita grouped by country levels of income (2017). N=155 countries; countries grouped by quartile of income GDP 2017 PPP-2011/cap.

Source: Own figure based on Global Network Footprint and World Bank database

\begin{tabular}{|c|c|c|}
\hline & Relationships between the indicator and GDP & Theoretical scenario \\
\hline Material Footprint & Material Footprint increase linearly with GDP & $\begin{array}{l}\text { Ecological Prevention. Degrowth } \\
\text { critique }\end{array}$ \\
\hline $\begin{array}{l}\text { Domestic Material } \\
\text { Consumption }\end{array}$ & $\begin{array}{c}\text { Diminishing Domestic Material Consumption with } \\
\text { higher GPD per capita }\end{array}$ & Productive Confidence \\
\hline Material Intensity & As GDP rises Material Intensity decreases & $\begin{array}{c}\text { Productive Confidence } \\
\text { Green Growth }\end{array}$ \\
\hline $\begin{array}{l}\text { Environmental Performance } \\
\text { Index }\end{array}$ & $\begin{array}{l}\text { As GDP rises the Environmental Performance Index } \\
\text { decreases }\end{array}$ & $\begin{array}{l}\text { Productive Confidence } \\
\text { Green Growth }\end{array}$ \\
\hline Ecological Footprint & $\begin{array}{c}\text { Ecological Footprint increases in the initial levels of } \\
\text { GDP to decrease later on, after a certain point of } \\
\text { return. }\end{array}$ & $\begin{array}{c}\text { Productive Confidence } \\
\text { Environmental Kuznets Curve }\end{array}$ \\
\hline Carbon Footprint & Carbon Footprint increase linearly with GDP & $\begin{array}{c}\text { Ecological Prevention. Degrowth } \\
\text { critique }\end{array}$ \\
\hline $\begin{array}{l}\mathrm{CO}_{2} \text { Emission (production- } \\
\text { based) }\end{array}$ & $\begin{array}{l}\text { CO2 Emission (production-based) increases in the } \\
\text { initial levels of GDP to decrease later on, after a } \\
\text { certain point of return. }\end{array}$ & $\begin{array}{c}\text { Productive Confidence } \\
\text { Environmental Kuznets Curve }\end{array}$ \\
\hline
\end{tabular}

Table 4: The relationship between selected indicators and indices, GDP and the theoretical scenarios. Source: Own table base on Environmental Performance Index database, UN Environment International Resource Panel, Environment Live / Global Material Flows and Global Footprint Network, Eora Miro Database, World Bank database 


\section{The Environmental Performance Index}

The Econometrics and Applied Statistics Unit at the European Commission Joint Research Centre previously criticized the Environmental Performance Index (EPI) (Athanasoglou et al. 2014; Saisana and Saltelli 2010). According to them, although several and different indicators compound the EPI, few are strong determinants of good environmental performance. They have questioned the differences between the weights that have been given to some indicators (that are compounding this index) and their real impact on it (ibid.). According to Saltelli et al. (2011) the weights used in Environmental Performance Index were not measures of importance, but rather measures of trade-offs among variables (see the Supplementary Document, Figure 1).

This is also true for the most recent 2018 Environmental Performance Index. Although it includes 24 different indicators, just five contribute the most to the ranking, namely: Exposure to indoor air pollution from Household Solid Fuels; Unsafe drinking water; Unsafe Sanitation; Lead exposure, and Wastewater treatment (for more information see the Supplementary Document). These five indicators are mainly about quality of life. They are measuring the quality of the air that we breathe, the quality of water that we drink or the access to or use of improved sanitation facilities. But none relate to increased resource depletion, or the use of water, materials, land, forests, energy and so on. Neither are they related to the generation of waste. As Martinez-Alier states, attention is drawn "away from material consumption and away from distributional conflicts" (MartinezAlier 1995a: 2). Although not "arbitrary" as Ravallion (2010) might argue, the choice of indicators is fundamental to the scores that the Index provides.

In common with the post-materialist thesis (Inglehart 1977), the Environmental Performance Index describes environmentalism not in terms of concern for the increasing depletion of resources, but on the contrary, in terms of a change in cultural values towards "quality of life" issues. This makes some countries - specifically richer ones - look good (or clean) in terms of environmental sustainability (Morse and Fraser 2005; Jesinghaus 2000). Further note that the indices produce this result by virtue of their parochialism and of the institutions and actors who decide to use them. They are only likely to be able to achieve this high level of environmental performance domestically - the international consequences of the environmental problems they export by virtue of their consumption demands are not within their purview. This is because the use of natural resources and emissions are measured on a territorial basis (IPCC, 2006). Thus, these indicators have not taken into account the material effects of relocation of resource intensive production.

As Jackson (2017) has argued, a significant proportion of the carbon emissions for which rich consumers are ultimately responsible (i.e., the carbon emitted from the factories in China where their consumption goods are made) end up being attributed to citizens in poorer countries. The material effects of relocation of resource intensive production are not being accounted for. Moreover, the indicators that are included in the Climate and Energy and Air Pollution issue categories are measured by unit of GDP. As was explained in the 2018 Environmental Performance Index Report (Wendling et al. 2018), Greenhouse gas (GHG) emissions must be divided by the size of each country's economy, as measured by GDP, to calculate carbon intensity. ${ }^{7}$ However, consuming less energy per unit of GDP does not mean that the total amount of consumed energy has decreased. In fact, countries that derive 'good' scores in terms of material intensity (the wealthy nations) are the ones who consume the most energy and materials per capita. We will return to this issue of dividing indicators by GDP when discussing Material intensity.

For instance, according to the $\mathrm{CO}_{2}$ Emission intensity indicator -included in the 2018 Environmental Performance Index- Seychelles was ranked well, and Burundi as one of the worst countries. However, if we do not control for GDP, but instead examine how emissions vary per capita, then the production-based $\mathrm{CO}_{2}$ emissions per capita in Seychelles in 2016 were 5.75 and in Burundi 0.54. What is worse, consumption-based $\mathrm{CO}_{2}$ emissions per capita in Seychelles were 12.45 metric tons, against 0.54 per capita metric tons in Burundi. High levels of $\mathrm{CO}_{2}$ emissions can be concealed.

\footnotetext{
${ }^{7}$ Apart from dividing emissions by GDP, more calculations have been done with the indicators for the categories of Climate and Energy and Air Pollution. For more information, see 2018 Technical Appendix of EPI (Wendling et al. 2018: 25-35).
} 
Finally, none of the 24 indicators that compound the Environmental Performance Index have been measured against planetary boundaries. This representation creates the illusion that the economy can continue to grow, without knowing if ecological limits have been breached.

\section{Domestic Material Consumption and $\mathrm{CO}_{2}$ emissions (production-based)}

Domestic Material Consumption per capita has a weak but still significant correlation with GDP. We found some high-income countries present a low level of Domestic Material Consumption in tons (see Figures 2). However, the scope of Domestic Material Consumption is limited to the amount of materials directly used by any national economy. It does not include the upstream raw materials related to imports and exports originating from outside the national economy. Hence if a car is imported, only its weight is counted, and not all the energy, water and other materials required to produce the metal, rubber and plastic it contains. In a globalized economy, where rich countries have outsourced much of their production to poorer countries, this side of material consumption has been shifted off their balance sheet (Hickel and Kallis 2019).

In 2017, high-income countries had the highest material footprint per capita (approximately 28 tons per person, Figure 6). The material footprint of wealthy nations is greater than their domestic material consumption, indicating that consumption in those countries relies on materials from other countries through international supply chains. Taking into account Material Footprint per capita, high-income countries rely on approximately 11.5 tons $^{8}$ per capita of primary materials extracted elsewhere in the world, over and above their Domestic Material Consumption. Hence, the Material Footprint indicator shows that the lifestyles of people in the richest countries are heavily dependent on resources extracted from poorer ones.

As we saw with Domestic Material Consumption, the scope of the $\mathrm{CO}_{2}$ emissions indicator is limited to the volume of emissions directly used by an economy. As we can observe in Figure 2 in the Supplementary Document when switching from $\mathrm{CO}_{2}$ emissions (production-based) to the Carbon Footprint measure, emissions increase linearly with GDP. This difference between production-based and consumption-based emissions have been labelled as "accumulation by displaced emissions" (Isenhour and Feng 2014), given that they allow for the reproduction of affluence in one context while attributing the mitigation responsibility and associated investment to another (Isenhour 2016). This avoids the root causes of the problem - growth in resource use and materials throughput — and it delays more substantive climate mitigation policy and action. Hornborg (2009) states that this situation outlines a zero-scenario, in which gains in one country are linked to increased costs in another. One of the tricks in the Environmental Performance Index is exposed: not taking the material effects of relocation of resource intensive production into account.

\section{Material Intensity}

Large footprints — either material, carbon or ecological — are negatively related with Material Intensity (Figure 1b). What is driving such contradictions? An improvement in the material intensity (i.e. the efficiency of material use) of economic output does not necessarily mean that material use itself is falling (Jackson and Victor 2019). Resource efficiency alone is not enough because "productivity gains in today's linear production system are likely to lead to increased material demand through a combination of economic growth and rebound effects' (UNEP 2017: 12 cited in Hickel and Kallis 2019: 8). As Jevons' Paradox states, an increase in resource efficiency leads indirectly to an absolute increase in the use of that resource (Kemp-Benedict 2018). Jevons' Paradox is well represented by Figure 1b (and Figures 1 in the Supplementary Document) when comparing Material, Carbon or Ecological Footprint with Material Intensity. Less Material Intensity means a large footprint. But note, one more question should be highlighted from these figures. The rich countries (shown as blue bubbles) are the ones who have less Material Intensity but the highest Footprints scores.

In fact, if an international sustainable policy is guided by Material Intensity, it suggests that poor countries are the ones who should reduce the use of natural resources, or at least improve the efficiency with which they use them. However, little attention is paid to the fact that in absolute amounts the richest countries

\footnotetext{
${ }^{8} 11$ tons per capita is the difference between Material Footprint per capita and Domestic Material consumption per capita
} in high income countries. 
are the ones who emit and consume the most. Here we find another device that has also been reported in the Environmental Performance Index: monitoring material or energy use per unit of GDP does not consider change in absolute or per capita terms.

The index of Material Intensity contains two further devices. Material consumption is measured as Domestic Material Consumption, which does not count the true costs of imported consumption. And, in addition to that, Domestic Material Consumption is divided by GDP. This means larger economies, particularly those inflated by large financial sectors, will receive smaller scores. That is why large footprints — either Material, Ecological or Carbon - correspond to lower Material Intensity.

Finally, Material Intensity has not been measured against ecological limits. This gives the illusion that rich countries can grow indefinitely because natural resources are unlimited and/or substitutable with manufactured capital. However, as Hickel (2018) has argued, materials are non-substitutable resources, and the efficiency gains are ultimately governed by physical limits. As efficiency improvements reach physical limits, the scale effect of growth drives total resource use up (Ward et al. 2016). Hence, growth in GDP ultimately cannot plausibly be decoupled from growth in material and energy use, demonstrating categorically that GDP growth cannot be sustained indefinitely (Hickel 2018).

\section{Ecological Footprint}

Although the Ecological Footprint has been identified as a strong sustainability indicator, we found a ruse in the way that this indicator calculates the Carbon Component. The Carbon Component estimates the area of forestland that is required to absorb all the carbon emissions from human activity in excess of what the oceans already absorb (for more details see Mancini et al., 2015 and the Supplementary Document). Such an approach can be associated with the theory of weak sustainability: the negative environmental consequences of producing manufactured capital ( $\mathrm{CO}_{2}$ emissions) can be easily replaced by natural capital (forestation). This fact involves the assumption of a so-called sustainable energy scenario under which $\mathrm{CO}_{2}$ is being captured by planting trees or forestation (Van den Bergh and Grazi 2013). Little attention is paid to the fact that carbon sequestration strategies need to consider their full environmental and social consequences. ${ }^{9}$

This may create a bias because at some point wealthy countries, which are also the counties who emit the most $\mathrm{CO}_{2}$, can offset their emission by planting trees. Hence, this represents another trick that could make rich countries look green and absolve them for taking drastic actions against climate change: assuming that carbon can be sequestered irrespective of the social and ecological contexts where that occurs. This in turn is part of a broader mechanism that seeks to use commodity trading (which tends to strip goods of their social and ecological content, see Kosoy and Corbera 2010) to attempt to solve environmental problems.

\section{Discussion: environmental sustainability measurements, tricks, and colonization}

Indicators that absolve wealthy countries of their culpability for causing pollution and environmental degradation perpetuate unequal exchange. They permit colonial forms of environmental governance, as political ecologists have repeatedly noted.

The forms, variety and intensity of colonization varies with each sustainability index or indicator and their theoretical and epistemological assumptions. The devices that we have identified (Table 5) make certain forms of environmental change, and environmental degradation, visible. Or, to paraphrase Robertson (2006) they create particular sorts of environments, and environmental change, that can be 'seen' by governments and international institutions.

The environment that wealthy countries can see most clearly is that captured by the Environmental Performance Index which is concerned with quality-of-life issues such as "air quality, access to clean water,

\footnotetext{
${ }^{9}$ Although trees are widely promoted to sequester carbon and to meet forest restoration goals, misplaced tree planting and forest expansion in ancient savannahs and grasslands threaten biodiversity and ecosystem services (Wiedmann et al. 2015). Jackson et al. (2005) also stressed that tree planting has always been a controversial method of soaking up $\mathrm{CO}_{2}$ because once the trees die, if they rot, then they release the carbon back into the atmosphere. Secure sequestration requires burying carbon.
} 
adequate sanitation or waste disposal" (Inglehart 1995, 57) or conserving pristine nature away from material consumption and away from economic distributional conflicts. By providing the results of a few indicators (such as water quality or the quality of the air) it can be argued not only that wealth increases appreciation of environmental values, but also that wealth is good for the environment.

However, as we have stressed, the Environmental Performance Index ignores planetary boundaries. This truncation might mislead assessments of national natural resource use and could hide the environmental implications of an infinite economic growth. If international institutions, such as UN, want to pursue a reduction of $\mathrm{CO}_{2}$ emissions rapid enough to stay with the carbon budget of $2^{\circ} \mathrm{C}$ targets, it should start to with a firm commitment to respecting planetary boundaries and seek to achieve human development within those limits (Hajer 2015). Such planetary boundaries, as we have shown, indicate that rich countries need to adopt degrowth strategies (Hickel 2018).

The other kind of environmentalism that wealthy countries are prepared to see is that of Ecological Modernization: the idea that continued economic expansion is compatible with our planet's ecology, because technological change and substitution will allow us absolutely to decouple GDP growth from resource use and carbon emissions (Hickel and Kallis 2019). However, such ideas conceal environmental problems hidden by capital.

First, decoupling is measured by indicators rendered in domestic production-based terms. Consequently, the richest countries can appear to reduce their national material consumption and emissions by moving material-intensive industries to other countries, generally to the Global South. Established privilege is blind to ecologically unequal exchange. Sharing responsibility for emissions and material use among producers and consumers could facilitate international agreement on global environmental policies that is now hindered by concerns over the regional and historical inequity of emission and material use. They export not just the causes but also the worst consequences of climate change. Although high-income countries are those emitting more $\mathrm{CO}_{2}$ emissions per capita, scientists at Notre Dame Global Adaptation Index calculated that people living in poor countries have 10 times more chance of being affected by a climate disaster than those in wealthy countries each year (Coffe 2016).

Second, indicators that are measuring decoupling are normally divided by GDP. As we have seen with the index of material intensity (DMC/GDP) and carbon intensity indicators, this mathematical device suggests poor countries should improve their environmental performance, belying the fact that the richest countries are those who consume the most natural resources per capita. As argued by Fletcher and Rammel (2017), decoupling acts as a distracting fantasy that warrants a (continuously more) destructive path with a promise of success. Demonstration of its impossibility is deferred into the future. But as absolute decoupling fails to materialize, natural resources continue to be depleted. In that sense, decoupling is more a threat than an opportunity. Ultimately, at the global level, what counts is the total amount of resources that are extracted from the ground, emitted into the atmosphere or consumed, and the possibility of regenerating these resources (Jackson, 2017). The final arbiter on material decoupling and the possibilities for escaping the dilemma of growth are worldwide trends on primary resource extraction and consumption (ibid.). In this vein, the amount of carbon dioxide going into the atmosphere today is more than 60\% greater than in 1990 (Jackson and Victor, 2019, see also the supplementary document). Human consumption of material resources has reached 91 billion tons per year, overshooting a sustainable level by $82 \%$ (Wiedmann et al. 2015; Bringezu et al. 2015). Needless to say, on per capita basis, the majority of this overshoot is due to consumption in high-income nations (Hickel 2019). Ultimately, "trying to reduce impacts while growing makes as little sense as trying to brake while accelerating in front of an obstacle" (Parrique et al. 2019: 59).

It is only by explaining economic growth without empirical reference to energy and material inputs that we are able to forget the environmental conditions and consequences of affluence (Martinez-Alier 1995b). Measurements indicating that economic growth is good for the environment downplay or ignore transboundary or spillover effects of the unsustainable consumption of nations in the Global North (Morse and Fraser 2005). Not making the mess in the first place should be preferable to cleaning it up later, but this is overlooked by such approaches. If we are going to label countries "good" or "bad" in environmental terms, we must get our measurements right. These measurements are "based on misleading data, which fail to take into account the 
true environmental costs that rich countries impose on the world, are designed to make dirty nations look clean" (The Ecologist 2001: 47).

\begin{tabular}{|c|c|c|}
\hline Tricks & Indicators & Actors \\
\hline $\begin{array}{c}\text { Focusing on "environmental issues" } \\
\text { away from material consumption } \\
\text { and away from distributional } \\
\text { conflicts" }\end{array}$ & Environmental Performance Index & The World Economic Forum \\
\hline \multirow{5}{*}{$\begin{array}{l}\text { Not taking all the material effects of } \\
\text { relocation into account }\end{array}$} & Climate and Energy indicators of the EPI & The World Economic Forum \\
\hline & Domestic Material Consumption & $\begin{array}{l}\text { UN (SDGs } 8 \text { AND 12), } \\
\text { OECD }\end{array}$ \\
\hline & Material Intensity (DMC/GDP) & $\begin{array}{l}\text { UN (SDGs } 8 \text { AND 12), } \\
\text { OECD }\end{array}$ \\
\hline & CO2 emissions production-based & UN, IPCC, World \\
\hline & Ecological Footprint & WWF \\
\hline \multirow{5}{*}{$\begin{array}{c}\text { Monitoring material or energy use } \\
\text { per unit of GDP or in growth rates } \\
\text { without considering the absolute } \\
\text { terms. }\end{array}$} & Climate and Energy indicators of the EPI & The World Economic Forum \\
\hline & Material Intensity (DMC/GDP) & $\begin{array}{l}\text { UN (SDGs } 8 \text { AND 12), } \\
\text { OECD }\end{array}$ \\
\hline & Material Footprint/GDP & UN (SDGs 8 AND 12) \\
\hline & $\mathrm{CO} 2$ emissions/GDP as an indicator & $\begin{array}{l}\text { UN (SDG 9), The World } \\
\text { Bank }\end{array}$ \\
\hline & Every indicator when it is used for measuring DECOUPLING & \\
\hline $\begin{array}{l}\text { Turning carbon (and other } \\
\text { pollutants) into commodities } \\
\text { without social and ecological } \\
\text { context }\end{array}$ & Ecological Footprint & WFF \\
\hline \multirow{4}{*}{$\begin{array}{l}\text { Not measuring tools against } \\
\text { planetary boundaries }\end{array}$} & Environmental Performance Index & The World Economic Forum \\
\hline & Material Intensity & UN (SDGs 8 AND 12) \\
\hline & Material Footprint/GDP & $\begin{array}{l}\text { UN (SDGs } 8 \text { AND 12), } \\
\text { OECD The World Bank }\end{array}$ \\
\hline & $\mathrm{CO} 2$ emissions/GDP as an indicator & $\begin{array}{l}\text { UN (SDG 9), The World } \\
\text { Bank }\end{array}$ \\
\hline
\end{tabular}

Table 5: Tricks, Indicators and Indices and actors.

\section{Conclusion}

As we stated at the beginning of this article, central to any colonial project is a particular way of seeing nature and society. This vision - of the present and for the future - makes it possible to identify groups of people who need to be governed in particular ways, or nature (land, resources) that needs to be used in particular ways. Colonization requires mapping, categorizing, surveillance and control. 
Decolonization therefore requires new ways of seeing nature and society, and some understanding of how the colonized visions operated - how colonizers constructed their image of what the world is like, and how it should be transformed. With respect to environmental and conservation policies we have to understand how different inequalities and injustices become engrained and sedimented into the world views we are challenging. Critics have long challenged the problems associated with particular categories of conservation interest (such as 'wilderness' and even biodiversity) that can structure conservation thought (Cronon 1995, Guyer and Richards 1996). But it is plain from our arguments above that the decolonization project must also extend to include the way in which we measure environmental change, degradation, amelioration and sustainability. Environmental sustainability indeces and indicators should consider the process of colonization that reproduces injustices within and across countries and enacts violence on racialized bodies, exacerbates class divisions, and damages our relationship with nature (Ricaurte, 2019).

The SDGs have stemmed from a global call to improve prosperity and environmental well-being. Through them international institutions are calling for action to protect the planet from degradation, through a wide range of changes to lifestyles, livelihoods, economies and societies. But this agenda begs vital questions: who should make which changes? What should be rich countries try and do, what should be poorer countries aim for?

The answers to these questions are plainly relevant to debates about decolonizing conservation and environmental governance. Simply put, current forms of environmental degradation are both a legacy of past trade, practices and resources use which have depended on unequal exploitation and consumption of resources in poor countries, and a consequence of ongoing international value chains in which production, and pollution, occurs in one country, but relatively benign consumption in others.

Indices and indicators that make rich countries look clean, are not just showing the environment that established wealth wants to see, it also hides the injustices and ecological-distributional conflicts that capital and society needs to see. Indices and indicators that try to hide the ecological debt are a product of what Quijano (2007: 1968) calls "Eurocentered colonial domination", mistakenly "... assumed to be 'objective', 'scientific', categories" and "...as natural phenomena, not referring to the history of power. This power structure was, and still is, the framework within which operate the other social relations of classes or estates." By analyzing indicators and indices that are relatively free from tricks it is very clear that the ones that are being dispossessed of natural resources "... are precisely the members of the 'races', 'ethnies', or 'nations' into which the colonized populations, were categorized in the formative process of the world power, from the conquest of America and onward" (Quijano, 2007: 169).

Sustainability indicators that are relatively free from tricks (i.e. the Carbon Footprint and Material Footprint) are easier to relate to environmental conflicts. For instance, in a country where exports of materials are much greater than imports of materials in tons (as is usually the case in Latin American and African countries) there are local environmental conflicts where minerals are mined; and within society at large, the perception of the economic and ecological inequality of foreign trade should grow (Muradian \& Martinez-Alier 2001; Giljum \& Eisenmenger 2004). There are historical and current conflicts over coal extraction (regarding the health of miners, land subsidence, production of Sulphur Dioxide) and oil extraction (over gas flaring, biodiversity loss), but also about the export of waste from rich to poor countries. At the global level, more fossil fuel extraction means more carbon dioxide production, which creates a conflict over the distribution of responsibilities and damages from climate change. These damages have been catalogued as an "ecological debt" from North to South, which includes the "carbon debt" i.e., damages from rich countries caused by excessive per capita emissions of carbon dioxide (the main effluent of affluence) and claims resulting from biopiracy, ecologically unequal exchange, and environmental liabilities by private corporations or northern governments (MartinezAlier 2009b). This is how the indicators of ecological unsustainability of the economy are linked to social and environmental conflicts (Martinez-Alier 2004).

At a global scale, Footprints show that Northern historical development and present production and consumption levels are reliant upon a socio-ecological 'subsidy' imposed on Southern countries (Rice 2009). The socioecological subsidy refers to the underpayment and, at times, explicit plundering, expropriation and looting of their natural resource assets and labor power. Such a situation, which began in the colonial era and continues unabated even today, not only enriches the North but also "impoverishes and degrades the land, 
culture, and development potential of Southern countries" (Rice 2009: 234). This ecological debt, or socioecological subsidy, represent injustices that present a prima facies case for decolonizing indices and indicators of environmental governance.

\section{References}

Apostolopoulou, E., \& Cortes-Vazquez, J. A. (Eds.). (2018). The right to nature: Social movements, environmental justice and neoliberal natures. Routledge.

Athanasoglou, S., Weziak-Bialowolska, D., \& Saisana, M. (2014). Environmental performance index 2014. JRC analysis and recommendations. JRC Science and Policy Reports (Vol. JRC89939). Ispra: JRC. Retrieved: http://citeseerx.ist.psu.edu/viewdoc/download?doi=10.1.1.729.4867\&rep=rep1\&type=pdf

Biermann, F. (2012). Planetary governance and earth system governance: Exploring the links. Journal of Ecological Economics, 81, 4-9. https://doi.org/10.1016/j.ecolecon.2012.02.016

Bringezu, S. (2015). Possible target corridor for sustainable use of global material resources. Resources 4(1), 25-54. https://doi.org/10.3390/resources4010025

Bullard, R. D. (1996). Environmental justice: It's more than waste facility siting. Social Science Quarterly, 77(3), 493-499.

Coffe, J. (2016) Why development should focus on climate adaptation. Just as climate change disproportionately affects the poor, so must efforts to reduce its toll. Ensia May 20. Retrieved from: https://ensia.com/voices/climate-change-disproportionately-hits-worlds-poorest

Costanza, R. \& Daly, H. (1992) Natural capital and sustainable development, Conservation Biology, 6(1): 3746.

Cronon, W. (1995). The trouble with wilderness: Or getting back to the wrong nature. In: Cronon, W. (Ed.). Uncommon ground: rethinking the human place in nature. W.W.Norton.

DeFries, R. S., Ellis, E. C., Chapin III, F. S., Matson, P. A., Turner, B. L. II, Agrawal, A., ... \& Lambin, E. (2012). Planetary opportunities: A social contract for global change science to contribute to a sustainable future. BioScience, 62(6), 603-606. https://doi.org/10.1525/bio.2012.62.6.11

Ekins, P., \& Simon, S. (2001). Estimating sustainability gaps: methods and preliminary applications for the UK and the Netherlands. Ecological Economics, 37(1), 5-22. https://doi.org/10.1016/S0921-8009(00)002792

Farley, (2014) Steady-State In D'Alisa, G., Demaria, F., \& Kallis, G. (Eds.). (2015). Degrowth: a vocabulary for a new era. Routledge

Fenton, A., Wright, H., Afionis, S., Paavola, J., \& Huq, S. (2014). Debt relief and financing climate change action. Nature Climate Change, 4(8), 650-653. https://doi.org/10.1038/nclimate2303

Fletcher, R., \& Rammelt, C. (2017). Decoupling: A key fantasy of the post-2015 sustainable development agenda. Globalizations, 14(3), 450-467. https://doi.org/10.1080/14747731.2016.1263077

García, E. (2004). Medio ambiente y sociedad: la civilización industrial y los límites del planeta. Anaya-Spain.

García, E. (2006). El cambio social más allá de los límites al crecimiento: un nuevo referente para el realismo en la sociología ecológica. Sociedad y Medio Ambiente, 27.

Giljum, S., \& Eisenmenger, N. (2004). North-South trade and the distribution of environmental goods and burdens: a biophysical perspective. The Journal of Environment \& Development, 13(1), 73-100. https://doi.org/10.1177/1070496503260974

Giljum, S., Dittrich, M., Lieber, M., \& Lutter, S. (2014). Global patterns of material flows and their socioeconomic and environmental implications: a MFA study on all countries world-wide from 1980 to 2009. Resources, 3(1), 319-339. https://doi.org/10.3390/resources3010319

Georgescu-Roegen N. (1971). The entropy law and the economic process. Harvard University Press.

Georgescu-Roegen, N. (1977). The steady state and ecological salvation: a thermodynamic analysis. BioScience, 27(4), 266-270. 
Grossman, G. M., \& Krueger, A. B. (1991). Environmental impacts of a North American Free Trade Agreement. Report No. w3914. National Bureau of Economic Research. http://doi.org/10.3386/w3914

Guha, R. \& Martínez-Alier, J. (1997). Varieties of environmentalism: essays North and South. Earthscan.

Guyer, J. \& P. Richards (1996). The invention of biodiversity: Social perspectives on the management of biological variety in Africa. Africa 66(1): 1-13.

Hajer, M., Nilsson, M., Raworth, K., Bakker, P., Berkhout, F., De Boer, Y., Rockström, J.... \& Kok, M. (2015). Beyond cockpit-ism: Four insights to enhance the transformative potential of the sustainable development goals. Sustainability, 7(2), 1651-1660. https://doi.org/10.3390/su7021651

Hauke, J., \& Kossowski, T. (2011). Comparison of values of Pearson's and Spearman's correlation coefficients on the same sets of data. Quaestiones Geographicae, 30(2), 87-93. https://doi.org/10.2478/v10117-0110021-1

Hickel, J. (2018). Is it possible to achieve a good life for all within planetary boundaries? Third World Quarterly, 40(1), 18-35. https://doi.org/10.1080/01436597.2018.1535895

Hickel, J. (2019). The contradiction of the sustainable development goals: Growth versus ecology on a finite planet. Sustainable Development, 27(5), 873-884. https://doi.org/10.1002/sd.1947

Hickel, J. (2020). The sustainable development index: Measuring the ecological efficiency of human development in the Anthropocene. Ecological Economics, 167, 106331.

Hickel, J., \& Kallis, G. (2019). Is green growth possible? New Political Economy, 25(4), 469-486. https://doi.org/10.1080/13563467.2019.1598964

Hornborg, Alf. (2009). Zero-Sum world: Challenges in conceptualizing environmental load displacement and ecologically unequal exchange in a world system. International Journal of Comparative Sociology 50, 237-262.

IBRD, 1992. Development and the environment. Oxford University Press.

Inglehart, R. (1977). The silent revolution: Changing values and political styles in advanced industrial society. Princeton University Press.

Inglehart, R. (1995). Public support for environmental protection: Objective problems and subjective values in 43 societies. PS: Political Science \& Politics, 28(1), 57-72. http://doi.org/10.2307/420583

IPCC. (2006). Guidelines for national greenhouse gas inventories. Eggleston, H.S., Buendia, L, Miwa, K, Ngara, T. \& Tanabe K. (Eds.). IGES, Japan.

Isenhour, C. (2014). Trading fat for forests: On palm oil, tropical forest conservation, and rational consumption. Conservation and Society, 12(3), 257-267. https://doi.org/10.4103/0972-4923.145136

Isenhour, C., \& Feng, K. (2016). Decoupling and displaced emissions: On Swedish consumers, Chinese producers and policy to address the climate impact of consumption. Journal of Cleaner Production, 134, 320-329.

Jackson J \& Victor P (2019) Unraveling the claims for (and against) green growth: Can the global economy grow indefinitely, decoupled from Earth's limitations? Science, 366 (6468), 950-951. DOI: 10.1126/science.aay0749

Jackson, T. (2009). Prosperity without growth: Economics for a finite planet. Earthscan.

Jackson, T. (2017). Prosperity without growth: Foundations for the economy of tomorrow. Routledge.

Jackson, R.B., Jobbagy, E.G., Avissar, R., Roy, S. B., Barrett, D. J., Cook, C.W., Farley, K.A., le Maitre, D.C., McCarl, B.A., \& Murray, B.C., 2005. Trading water for carbon with biological carbon sequestration. Science 310, 1944-1947. DOI: 10.1126/science.1119282

Jesinghaus, J. (2000). The World Economic Forum's Environmental Sustainability Index: Strong and weak points. European Commission Joint Research Centre.

Jevons, W. S. (1865). The coal question: An inquiry concerning the progress of the nation, and the probable exhaustion of our coal mines. MacMillan.

Kallis, G. (2011). In defence of degrowth. Ecological Economics, 70(5), 873-880. https://doi.org/10.1016/J.ECOLECON.2010.12.007 
Kallis, G. (2017). Radical dematerialization and degrowth. Philosophical Transactions of the Royal Society A, 375(2095), 20160383. https://doi.org/10.1098/rsta.2016.0383

Kemp-Benedict, E. (2018). Dematerialization, decoupling, and productivity change. Ecological Economics, 150, 204-216. https://doi.org/10.1016/j.ecolecon.2018.04.020

Kerschner, C. (2010). Economic de-growth vs. steady-state economy. Journal of Cleaner Production, 18(6), 544-551.

Kosoy, N. \& Corbera, E. (2010). Payments for ecosystem services as commodity fetishism. Ecological Economics 69, 1228-1236.

Kuznets, S. (1955). Economic growth and income inequality. American Economic Review, 65, 1-28.

Latouche, S. (2006). Le pari de la décroissance. Fayard.

Lélé, S., \& Norgaard, R. B. (1996). Sustainability and the scientist's burden. Conservation Biology, 10(2), 354365.

Lele, S., Brondizio, E. S., Byrne, J., Mace, G. M., \& Martinez-Alier, J. (2018). Framing the environment. In Lele, S., Brondizio, E. S., Byrne, J., Mace, G. M., \& Martinez-Alier, J. (Eds.). Rethinking environmentalism: Linking justice sustainability and diversity, (pp. 1-19). MIT Press.

Martinez-Alier, J. (1995a). The environment as a luxury good or "too poor to be green"? Ecological Economics, 13(1), 1-10.

Martinez-Alier, J. (1995b). Political ecology, distributional conflicts, and economic incommensurability. New Left Review, 1/211, 70-70.

Martínez-Alier, J. (1997). Environmental justice (local and global). Capitalism Nature Socialism, 8(1), 91-107.

Martínez-Alier, J. (2002). The environmentalism of the poor: a study of ecological conflicts and valuation. Edward Elgar.

Martinez-Alier, J. (2004). Ecological distribution conflicts and indicators of sustainability. International Journal of Political Economy, 34(1), 13-30.

Martinez-Alier, J. M. (2009a). Socially sustainable economic de-growth. Development and Change, 40(6), 1099-1119.

Martinez-Alier, J. M. (2009b). Social metabolism, ecological distribution conflicts, and languages of valuation. Capitalism Nature Socialism, 20(1), 58-87. https://doi.org/10.1080/10455750902727378

Martinez-Alier, J. (2014) Environmentalism, currents of. In D'Alisa, G., Demaria, F., \& Kallis, G. (Eds.). Degrowth: a vocabulary for a new era. Routledge.

Martinez-Alier, J., \& O'Connor, M. (1996). Ecological and economic distribution conflicts. In R. Costanza, R., Segura, O. \& Martinez-Alier, J. (Eds.). Getting down to Earth: Practical applications of ecological economics (pp. 153-183). Island Press.

Mazzucato, M. (2018). The value of everything: Making and taking in the global economy. Hachette.

Morse, S., \& Fraser, E. D. (2005). Making 'dirty' nations look clean? The nation state and the problem of selecting and weighting indices as tools for measuring progress towards sustainability. Geoforum, 36(5), 625-640.

Muradian, R. \& J. Martinez-Alier. (2001). Trade and environment - from a 'Southern' perspective. Ecological Economics 36(2), 281-297.

O'Neill, D. W., Fanning, A. L., Lamb, W. F., \& Steinberger, J. K. (2018). A good life for all within planetary boundaries. Nature Sustainability, 1(2), 88-95. https://doi.org/10.1038/s41893-018-0021-4

Parrique, T., Barth, J., Briens, F., Kerschner, C., Kraus-Polk, A., Kuokkanen, A., \& Spangenberg, J. H. (2019). Decoupling debunked - evidence and arguments against green growth as a sole strategy for sustainability. European Environment Bureau, EEB.

Pearce, D. W. \& Atkinson, G. D. (1993). Capital theory and the measurement of sustainable development: An indicator of "weak" sustainability. Ecological Economics, 8(2), 103-108.

Quijano, A. (2007). Coloniality and modernity/rationality. Cultural Studies, 21(2-3): 168-178. 
Ravallion, M. (2010). Mashup indices of development. Policy Research Working Papers, The World Bank. https://doi.org/10.1596/1813-9450-5432

Raworth (2012), A safe and just space for humanity: Can we live within the doughnut? Oxfam Discussion Papers. Oxfam.

Rice, J. (2009). North south relations and the ecological debt: Asserting a counterhegemonic discourse. Critical Sociology 35, 225-252.

Ricaurte, P. (2019). Data epistemologies, the coloniality of power, and resistance. Television \& New Media, 20(4), 350-365. https://doi.org/10.1177/1527476419831640

Robertson, M. M. (2006). The nature that capital can see: Science, state, and market in the commodification of ecosystem services. Environment and Planning D: Society and Space, 24(3), 367-387.

Rockström, J., Steffen, W., Noone, K., Persson, Å., Chapin III, F. S., Lambin, E., ... \& Foley, J. (2009). Planetary boundaries: Exploring the safe operating space for humanity. Ecology and Society, 14(2).

Saisana, M., \& Saltelli, A. (2010). Uncertainty and sensitivity analysis of the 2010 Environmental Performance Index. Office of Official Publications of the European Communities.

Saltelli, A. \& Saisana, M. et al. (2011). Weights and importance in linear aggregation. Proc. 58th World Statistical Congress, 2011, Dublin.

Schneider, F., Kallis, G., \& Martinez-Alier, J. (2010). Crisis or opportunity? Economic degrowth for social equity and ecological sustainability. Journal of Cleaner Production, 18(6), 511-518.

Simko, K., Klawitter, S. \& Rider, M. (2014) Weak sustainability: Just keep swimming. Mar 27. Retrieved from https://blogs.lt.vt.edu/mksnav

Smith-Spash, T. (2014). How should degrowth address the issue of "planetary boundaries"? Degrowth Conference Leipzig 2014.

Solow, R. M. (1957). Technical change and the aggregate production function. The Review of Economics and Statistics, 39(3), 312-320.

Steinberger, J. K., Krausmann, F., Getzner, M., Schandl, H., \& West, J. (2013). Development and dematerialization: an international study. PloS One, 8(10). https://doi.org/10.1371/journal.pone.0070385

Taibo, C. (2009). Doce preguntas sobre el decrecimiento. Libre Pensamiento, 61, 16-21.

The Ecologist and Friends of the Earth. 2001. Keeping score: which countries are the most sustainable? The Ecologist 31(3): 44.

United Nations Environment Programme (UNEP), 2011. Towards a green economy: pathways to sustainable development and poverty eradication - a synthesis for policy makers. UNEP.

Van den Bergh, J. C., \& Grazi, F. (2014). Ecological footprint policy? Land use as an environmental indicator. Journal of Industrial Ecology, 18(1), 10-19.

Wendling, Z. A., Emerson, J. W., Esty, D. C., Levy, M. A., de Sherbinin, A., et al. (2018). 2018 Environmental Performance Index. Yale Center for Environmental Law \& Policy. https://epi.yale.edu

Wiedmann, T. O., Schandl, H., Lenzen, M., Moran, D., Suh, S., West, J., \& Kanemoto, K. (2015). The material footprint of nations. Proceedings of the National Academy of Sciences, 112(20), 6271-6276. https://doi.org/10.1073/pnas.1220362110

Wiedmann, T., Lenzen, M., Keyßer, L. T., \& Steinberger, J. K. (2020). Scientists' warning on affluence. Nature Communications, 11(1), 1-10. https://doi.org/10.1038/s41467-020-16941-y

World Bank (2012). Inclusive green growth: The pathway to sustainable development. World Bank. 